\title{
Anthropogenic imprints on nitrogen and oxygen isotopic composition of precipitation nitrate in a nitrogen-polluted city in southern China
}

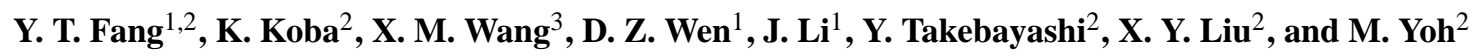 \\ ${ }^{1}$ South China Botanical Garden, Chinese Academy of Sciences, Guangzhou 510650, China \\ ${ }^{2}$ Tokyo University of Agriculture and Technology, Tokyo 183 8509, Japan \\ ${ }^{3}$ School of Environmental Science and Engineering, Sun Yat-Sen University, Guangzhou 501275, China
}

Received: 4 September 2010 - Published in Atmos. Chem. Phys. Discuss.: 8 September 2010

Revised: 4 February 2011 - Accepted: 5 February 2011 - Published: 15 February 2011

\begin{abstract}
Nitric acid $\left(\mathrm{HNO}_{3}\right)$ or nitrate $\left(\mathrm{NO}_{3}^{-}\right)$is the dominant sink for reactive nitrogen oxides $\left(\mathrm{NO}_{\mathrm{x}}=\mathrm{NO}+\mathrm{NO}_{2}\right)$ in the atmosphere. In many Chinese cities, $\mathrm{HNO}_{3}$ is becoming a significant contributor to acid deposition. In the present study, we measured nitrogen $(\mathrm{N})$ and oxygen $(\mathrm{O})$ isotopic composition of $\mathrm{NO}_{3}^{-}$in 113 precipitation samples collected from Guangzhou City in southern China over a twoyear period (2008 and 2009). We attempted to better understand the spatial and seasonal variability of atmospheric $\mathrm{NO}_{\mathrm{x}}$ sources and the $\mathrm{NO}_{3}^{-}$formation pathways in this $\mathrm{N}$ polluted city in the Pearl River Delta region. The $\delta^{15} \mathrm{~N}$ values of $\mathrm{NO}_{3}^{-}$(versus air $\mathrm{N}_{2}$ ) ranged from -4.9 to $+10.1 \%$, and averaged $+3.9 \%$ in 2008 and $+3.3 \%$ in 2009 . Positive $\delta^{15} \mathrm{~N}$ values were observed throughout the year, indicating the anthropogenic contribution of $\mathrm{NO}_{\mathrm{x}}$ emissions, particularly from coal combustion. Different seasonal patterns of $\delta^{15} \mathrm{~N}^{-\mathrm{NO}_{3}^{-}}$were observed between 2008 and 2009, which might reflect different human activities associated with the global financial crisis and the intensive preparations for the 16th Asian Games. Nitrate $\delta^{18} \mathrm{O}$ values (versus Vienna Standard Mean Ocean Water) varied from +33.4 to $+86.5 \%$ (average $+65.0 \%$ and $+67.0 \%$ in 2008 and 2009 , respectively), a range being lower than those reported for high latitude and polar areas. Sixteen percent of $\delta^{18} \mathrm{O}$ values was observed lower than the expected minimum of $+55 \%$ at our study site. This was likely caused by the reaction of $\mathrm{NO}$ with peroxy radicals; peroxy radicals can compete with $\mathrm{O}_{3}$ to convert $\mathrm{NO}$ to $\mathrm{NO}_{2}$, thereby donate $\mathrm{O}$ atoms with much lower $\delta^{18} \mathrm{O}$ value
\end{abstract}

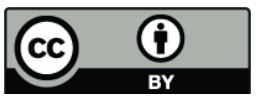

Correspondence to: Y. T. Fang

(fangyt@scbg.ac.cn) than that of $\mathrm{O}_{3}$ to atmospheric $\mathrm{NO}_{3}^{-}$. Our results highlight that the influence of human activities on atmospheric chemistry can be recorded by the $\mathrm{N}$ and $\mathrm{O}$ isotopic composition of atmospheric $\mathrm{NO}_{3}^{-}$in a $\mathrm{N}$-polluted city.

\section{Introduction}

Global atmospheric emissions of nitrogen oxides $\left(\mathrm{NO}_{\mathrm{x}}\right.$, the sum of $\mathrm{NO}$ and $\mathrm{NO}_{2}$ ) have increased dramatically during the past 150 years (Galloway et al., 2004, 2008). Current global $\mathrm{NO}_{\mathrm{x}}$ emissions are dominated by fossil fuel combustion $(63 \%)$ and far exceed natural $\mathrm{NO}_{\mathrm{x}}$ sources, such as lightning, biogenic soil processes, and wildfires (Ehhalt et al., 2001). $\mathrm{NO}_{\mathrm{x}}$ contributes to the formation of ozone $\left(\mathrm{O}_{3}\right)$ and particulate matter and is thus an important factor affecting regional air quality and radiative balance (Ehhalt et al., 2001). Once emitted to the atmosphere, $\mathrm{NO}_{\mathrm{x}}$ is oxidized via several pathways to form highly soluble nitric acid $\left(\mathrm{HNO}_{3}\right)$, which is then dissolved in precipitation or collected on aerosols and subsequently scavenged from the atmosphere as wet or dry deposition (Ehhalt et al., 2001; Elliott et al., 2009). The elevated atmospheric deposition of $\mathrm{NO}_{3}^{-}$associated with increased $\mathrm{NO}_{\mathrm{x}}$ emissions also poses many ecological and environmental threats, including the acidification of soil and surface water, the eutrophication of lakes, rivers, and estuaries, the loss of biodiversity, and the alteration of global carbon budget (Vitousek et al., 1997; Aber et al., 1998; Gundersen et al., 1998; Fang et al., 2008; Galloway et al., 2008).

The growth rate in $\mathrm{NO}_{\mathrm{x}}$ emissions is expected to have shifted from North America and Europe to Asia (Ehhalt et al., 2001). In China, $\mathrm{HNO}_{3}$ is becoming a significant contributor

Published by Copernicus Publications on behalf of the European Geosciences Union. 
to acid rain due to the increased vehicle usage and power plant emissions (Zheng et al., 2009; Wang et al., 2010), and to the control on $\mathrm{SO}_{2}$ emissions (Zhao et al., 2009) in many cities. For example, in Guangzhou City in southern China, the molar ratios of sulfate $\left(\mathrm{SO}_{4}^{2-}\right)$ to $\mathrm{NO}_{3}^{-}$in precipitation have decreased continuously from 4.6 in 1986-1990 to 2.8 in the 1990s and to 1.5 in the 2000s (Fig. 1). Thus, it is important to recognize and separate the anthropogenic production of $\mathrm{NO}_{\mathrm{x}}$ (and therefore $\mathrm{NO}_{3}^{-}$) from natural processes (e.g., soil emissions, biomass burning, and lightning) in order to assess the impact of anthropogenic input on the atmospheric cycle and the budget of reactive $\mathrm{N}$ (Ehhalt et al., 2001). The identification of $\mathrm{NO}_{\mathrm{x}}$ sources at any given location is also vital to develop sound regulatory management and mitigation strategies for air and water quality (Elliott et al., 2007, 2009).

Once released to the atmosphere, $\mathrm{NO}_{\mathrm{x}}$ is converted to atmospheric $\mathrm{NO}_{3}^{-}$through a number of chemical pathways (Seinfeld and Pandis, 1998; Finlayson-Pitts and Pitts, 2000). Most tropospheric $\mathrm{NO}_{\mathrm{x}}$ is emitted as $\mathrm{NO}$, which photochemically equilibrates during the daytime with $\mathrm{NO}_{2}$ within a few minutes (Reactions R1 and R2); this $\mathrm{NO}_{2}$ is further oxidized via several major chemical reaction pathways. During the day, the photolytic production of hydroxyl $(\mathrm{OH})$ radical results in the oxidation of $\mathrm{NO}_{2}$ to $\mathrm{HNO}_{3}(\mathrm{~g})$ via the $\mathrm{OH}$ radical (Reaction R3). This pathway is also most prevalent in summer when the concentrations of photochemically produced $\mathrm{OH}$ radicals are the highest (Calvert et al., 1985); this is termed the $\mathrm{OH}$ pathway hereafter. At nighttime, $\mathrm{NO}_{2}$ is oxidized by $\mathrm{O}_{3}$ to produce $\mathrm{NO}_{3}$ radical $\left(\mathrm{NO}_{3}\right)$ (reaction $\mathrm{R} 4$ ), which subsequently combines with $\mathrm{NO}_{2}$ to form dinitrogen pentoxide $\left(\mathrm{N}_{2} \mathrm{O}_{5}\right)$ (Reaction R5). The hydrolysis of $\mathrm{N}_{2} \mathrm{O}_{5}$ yields $\mathrm{HNO}_{3}(\mathrm{~g})$ (Reaction R6). This pathway is most prevalent during winter as $\mathrm{N}_{2} \mathrm{O}_{5}$ is thermally unstable (Calvert et al., 1985), and is termed the $\mathrm{N}_{2} \mathrm{O}_{5}$ pathway hereafter.

$$
\begin{aligned}
& \mathrm{NO}+\mathrm{O}_{3} \rightarrow \mathrm{NO}_{2}+\mathrm{O}_{2} \\
& \mathrm{NO}_{2}+h v \rightarrow \mathrm{NO}+\mathrm{O} \\
& \mathrm{NO}_{2}+\mathrm{OH} \rightarrow \mathrm{HNO}_{3} \\
& \mathrm{NO}_{2}+\mathrm{O}_{3} \rightarrow \mathrm{NO}_{3}+\mathrm{O}_{2} \\
& \mathrm{NO}_{3}+\mathrm{NO}_{2} \leftrightarrow \mathrm{N}_{2} \mathrm{O}_{5} \\
& \mathrm{~N}_{2} \mathrm{O}_{5}+\mathrm{H}_{2} \mathrm{O}_{\text {(surface) }} \rightarrow \mathrm{HNO}_{3}
\end{aligned}
$$

The $\mathrm{N}$ stable isotopic composition of atmospheric deposition has often been viewed as reflecting $\mathrm{NO}_{\mathrm{x}}$ source because $\mathrm{N}$ atoms are conserved during the transformation of $\mathrm{NO}_{\mathrm{x}}$ into $\mathrm{NO}_{3}^{-}$in the atmosphere (Moore, 1977; Freyer, 1991; Heaton, 1990; Hastings et al., 2003), although $\mathrm{N}$ isotopic fractionation may also occur during atmospheric transformations and during the transport of atmospheric $\mathrm{NO}_{3}^{-}$. The $\delta^{15} \mathrm{~N}$ values of anthropogenic and natural $\mathrm{NO}_{\mathrm{x}}$ sources vary over a large range. The $\mathrm{NO}_{\mathrm{x}}$ emitted by anthropogenic sources can

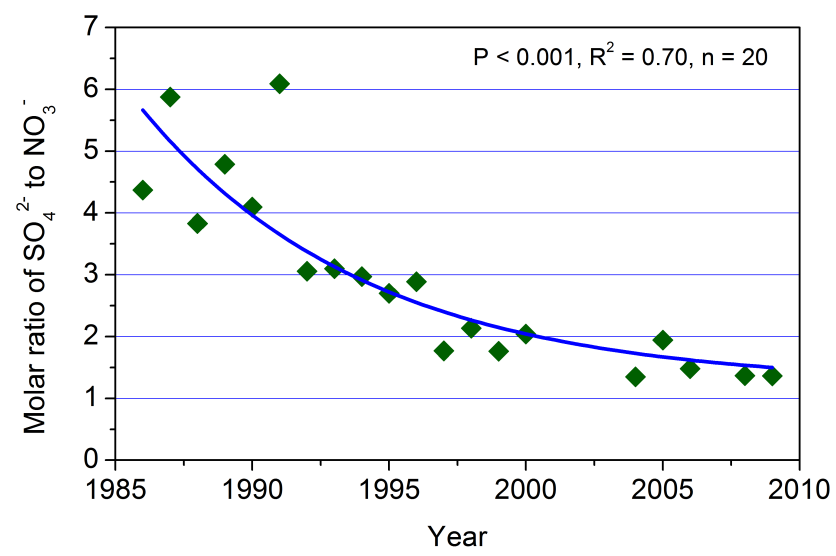

Fig. 1. Molar ratios of $\mathrm{SO}_{4}^{2-}$ to $\mathrm{NO}_{3}^{-}$in precipitation in Guangzhou City during the period from 1986 to 2009. Data are from Quan et al. (1992) for 1986 to 1990, Ye et al. (2008) for 1991 to 2000, Liu et al. (2006) for 2004, Huang et al. (2009) for 2005, Cao et al. (2009) for 2006, and this study for 2008 and 2009.

be classified into two groups, fuel $\mathrm{NO}_{\mathrm{x}}$ (i.e., the oxidation of $\mathrm{N}$ initially contained in the fuel) and thermal $\mathrm{NO}_{\mathrm{x}}$ (i.e., high-temperature conversion of atmospheric $\mathrm{N}_{2}$ and $\mathrm{O}_{2}$ to $\mathrm{NO}_{\mathrm{x}}$ ) (Snape et al., 2003; Widory, 2007). The fuel $\mathrm{NO}_{\mathrm{x}}$ generally shows positive values. For instance, the $\delta^{15} \mathrm{~N}$ of $\mathrm{NO}_{\mathrm{x}}$ from coal-fired power plants range from +5 to $+13 \%$ o (Heaton, 1990; Kiga et al., 2000) and was determined on the order of $+15 \pm 2 \%$ o (Snape et al., 2003). In contrast, the $\delta^{15} \mathrm{~N}$ of thermal $\mathrm{NO}_{\mathrm{x}}$ exhibits negative values. Heaton (1990) reported the $\delta^{15} \mathrm{~N}$ values of $\mathrm{NO}_{\mathrm{x}}$ for vehicle exhaust of -13 to $-2 \%$ o under different loads. Snape et al. (2003) measured values on the order of $-6.2 \pm 0.9$ from the exhaust of an industrial plant. The $\delta^{15} \mathrm{~N}$ of vehicular $\mathrm{NO}_{\mathrm{x}}$ are determined by the relative proportion of thermal and fuel $\mathrm{NO}_{\mathrm{x}}$ produced in car and truck engines. The $\mathrm{NO}_{\mathrm{x}}$ emissions measured from tailpipe exhaust, roadside denuders, and roadside vegetation have $\delta^{15} \mathrm{~N}$ values of $+3.7,+5.7$, and $+3.8 \%$, respectively (Moore, 1977; Ammann et al., 1999; Pearson et al., 2000). The $\delta^{15} \mathrm{~N}$ values of natural $\mathrm{NO}_{\mathrm{x}}$ sources, including lightning, biogenic $\mathrm{NO}_{\mathrm{x}}$ emissions, and biomass burning, have not yet been well quantified. Hoering (1957) reported that the $\delta^{15} \mathrm{~N}$ values of $\mathrm{NO}_{\mathrm{x}}$ produced during electrical discharge used to simulate lightning range from -0.5 to $+1.4 \%$ o. The $\delta^{15} \mathrm{~N}$ values are -48 to $-20 \%$ o for NO emitted by fertilized soil (Li and Wang, 2008). Low $\delta^{15} \mathrm{~N}$ values were found at pristine sites relative to polluted sites (Moore, 1977; Pearson et al., 2000), and during spring and summer relative to other seasons (Freyer, 1991; Russell et al., 1998).

Oxygen isotopic fractionation can induce large variations in $\delta^{18} \mathrm{O}$ values between the reactants and the products during atmospheric transformation (see e.g., Chakraborty and Chakraborty, 2003), but $\delta^{18} \mathrm{O}$ of atmospheric $\mathrm{NO}_{3}^{-}$is considered to be mostly related to oxidation pathways in the atmosphere, involving such atmospheric oxidants as $\mathrm{O}_{3}, \mathrm{OH}$ 
radicals, peroxy radicals, and halogen oxides (Hastings et al., 2003, 2004; Michalski et al., 2003; Morin et al., 2008, 2009; Alexander et al., 2009). The oxidation reactions are influenced by many factors, including temperature, humidity, solar radiation, and the availability of reactive aerosol surfaces (Wankel et al., 2010). The $\delta^{18} \mathrm{O}$ values of atmospheric $\mathrm{NO}_{3}^{-}$are mostly controlled by the seasonality of the chemical oxidation pathways (Reactions R1-R6) due to the high $\delta^{18} \mathrm{O}$ values contributed by tropospheric $\mathrm{O}_{3}(+90$ to $+120 \%$, Krankowsky et al., 1995; Johnston and Thiemens, 1997) during $\mathrm{NO}_{3}^{-}$formation (Hastings et al., 2003; Michalski et al., 2003). The $\mathrm{O}$ isotopic composition of $\mathrm{HNO}_{3}$ formed by the $\mathrm{OH}$ pathway reflects the contribution of up to $2 / 3 \mathrm{O}_{3}$ and $1 / 3$ $\mathrm{OH}$, whereas the $\mathrm{O}$ isotopic composition of $\mathrm{HNO}_{3}$ formed by the $\mathrm{N}_{2} \mathrm{O}_{5}$ pathway reflects the contribution of up to $5 / 6$ $\mathrm{O}_{3}$ and $1 / 6 \mathrm{H}_{2} \mathrm{O}$ (Hastings et al., 2003). Thus, atmospheric $\mathrm{NO}_{3}^{-}$formed via the $\mathrm{OH}$ pathway has lower $\delta^{18} \mathrm{O}$ values than that formed via the $\mathrm{N}_{2} \mathrm{O}_{5}$ pathway. The $\mathrm{N}_{2} \mathrm{O}_{5}$ pathway is more important in winter than in summer due to the longer nighttime in the former. This explains the higher $\delta^{18} \mathrm{O}$ of atmospheric $\mathrm{NO}_{3}^{-}$in winter than in summer in previous studies (Hastings et al., 2003, 2004; Elliott et al., 2007, 2009; Morin et al., 2008, 2009; Wankel et al., 2010).

The dual isotopes of atmospheric $\mathrm{NO}_{3}^{-}$have been intensively analyzed in middle and high latitude regions in an effort to constrain $\mathrm{NO}_{\mathrm{x}}$ sources and formation pathways (Hastings et al., 2003; Elliott et al., 2007, 2009; Morin et al., 2008, 2009). For instance, Elliott et al. (2007, 2009) demonstrated a strong correlation between wet deposition $\delta^{15} \mathrm{~N}^{-\mathrm{NO}_{3}^{-}}$and proximity of stationary source (e.g., power plant facilities) $\mathrm{NO}_{\mathrm{x}}$ emissions in the northeastern US, with higher $\delta^{15} \mathrm{~N}$ values (up to $+3.2 \%$ ) found in areas affected by higher $\mathrm{NO}_{\mathrm{x}}$ emissions, suggesting that the nitrate isotope is a promising tool to constrain $\mathrm{NO}_{\mathrm{x}}$ sources to a given location. To date, little work has been done to characterize the dual isotopic composition of atmospheric $\mathrm{N}$ deposition in low latitude regions (Morin et al., 2009; Wankel et al., 2010), particularly in a location with complex air pollution under warm and humid conditions, such as the city we studied.

In this study, we measured the $\mathrm{N}$ and $\mathrm{O}$ isotopic composition of $\mathrm{NO}_{3}^{-}$in 113 precipitation samples collected from Guangzhou City in southern China over a two-year period (2008 and 2009). Guangzhou City is located in the center of the Pearl River Delta. It is highly populated and is one of the major economic centers in China. In the last three decades, rapid economic development has led to complex and regional air pollution problems, such as acid rain, photochemical smog, and haze, over this region (Wang et al., 2003, 2007, 2010; Zhang et al., 2008a; Zheng et al., 2009). We attempted to better understand the spatial and seasonal variability of atmospheric $\mathrm{NO}_{\mathrm{x}}$ sources in this N-polluted city and the $\mathrm{NO}_{3}^{-}$formation pathways in combination with air mass back trajectory analysis, which would help us evaluate the impact of urban development and industrialization on the $\mathrm{N}$ input to the study region.
Our hypotheses were that in the study city, (1) there would be a distinct seasonal pattern of $\delta^{15} \mathrm{~N}-\mathrm{NO}_{3}^{-}$in precipitation with lower values in the warm season due to a higher contribution from biogenic sources (e.g., soil emissions) and the prevailing southern winds from South China Sea, which bring relatively clean air masses to the study city, than in the cool season; (2) due to anthropogenic $\mathrm{N}$ emissions, $\delta^{15} \mathrm{~N}$ $\mathrm{NO}_{3}^{-}$values would be higher than those of other remote areas; (3) $\delta^{18} \mathrm{O}-\mathrm{NO}_{3}^{-}$would be lower in the warm season than in the cool season due to the longer daytime in the warm season, as previously reported (Hastings et al., 2003, 2007; Elliott et al., 2009), but the seasonal variation would be small compared to those of high latitude and polar areas; and (4) $\delta^{18} \mathrm{O}-\mathrm{NO}_{3}^{-}$would be lower than those of high latitude and polar areas due to the relative longer daytime and the more abundant water vapor, as our study site is close to the equator (humid tropical climate). However, we also expected that the seasonal $\mathrm{N}$ and $\mathrm{O}$ isotopic patterns might have been affected by the energy consumption pattern associated with certain events, such as the global financial crisis in 2008 and the intensive construction activities preparing for the 16th Asian Games in 2009.

\section{Methods}

\subsection{Sampling}

From 2008 to 2009, bulk precipitation was collected in the South China Botanical Garden $\left(23.2^{\circ} \mathrm{N}, 113.3^{\circ} \mathrm{E}\right)$ of Guangzhou City on a daily basis. In some months, no precipitation could be sampled owing to the small volume and the prolonged drought, which resulted in an underestimation of the annual precipitation $\mathrm{N}$ input. Precipitation was collected with an open funnel $(23 \mathrm{~cm}$ in diameter) that was connected to a $5 \mathrm{~L}$ sampling bottle with a black polypropylene tube. The collector was washed with distilled water immediately after each collection. Samples were filtered within $24 \mathrm{~h}$ of collection through $0.45 \mu \mathrm{m}$ filters in the laboratory, and then stored in plastic bottles at $4{ }^{\circ} \mathrm{C}$ until chemical analysis.

\subsection{Chemical and isotope analyses}

The concentrations of major ions, including $\mathrm{NH}_{4}^{+}, \mathrm{NO}_{2}^{-}$, and $\mathrm{NO}_{3}^{-}$, in all precipitation samples were determined by ion chromatography (Dionex DX-120, Osaka, Japan). The $\delta^{15} \mathrm{~N}$ (versus air $\mathrm{N}_{2}$ ) and $\delta^{18} \mathrm{O}$ (versus Vienna Standard Mean Ocean Water) values of $\mathrm{NO}_{3}^{-}$in precipitation were measured using the denitrifier method (Sigman et al., 2001; Casciotti et al., 2002), with an isotope-ratio mass spectrometer (Delta XP; Thermo Fisher Scientific K.K., Yokohama, Japan) coupled with a gas chromatograph (HP6890; Hewlett Packard Co., Palo Alto, CA, USA) equipped with a PoraPLOT column $(25 \mathrm{~m} \times 0.32 \mathrm{~mm})$ and GC interface III (Thermo Fisher Scientific K. K., Yokohama, Japan). 
The denitrifying bacterium, Pseudomonas aureofaciens, was used to convert $25 \mathrm{nmol}$ of $\mathrm{NO}_{3}^{-}$into gaseous $\mathrm{N}_{2} \mathrm{O}$ in $20 \mathrm{~mL}$ vials prior to isotope analysis. We ran several standards (USGS32, 34, and 35, and IAEA $\mathrm{NO}_{3}^{-}$) to obtain the calibration curve to correct for drift, oxygen isotope exchange, and blank. The average standard deviations for replicate analysis of an individual sample were $\pm 0.2 \%$ for $\delta^{15} \mathrm{~N}_{\text {of }} \mathrm{NO}_{3}^{-}$and $\pm 0.5 \%$ or or $\delta^{18} \mathrm{O}$.

Atmospheric $\mathrm{NO}_{3}^{-}$is anomalously enriched in both the ${ }^{18} \mathrm{O} /{ }^{16} \mathrm{O}$ and ${ }^{17} \mathrm{O} /{ }^{16} \mathrm{O}$ isotopic ratios, due to the transfer from $\mathrm{O}_{3}$ to $\mathrm{HNO}_{3}$ during $\mathrm{NO}_{\mathrm{x}}$ oxidation reactions (Michalski et al., 2003). The use of the denitrifier method for $\delta^{15} \mathrm{~N}$ measurements thus requires correction for the contribution of the mass-independent ${ }^{14} \mathrm{~N}-{ }^{14} \mathrm{~N}-{ }^{17} \mathrm{O}$ (the $\mathrm{m} / \mathrm{z} 45$ signal) to the analyte $\mathrm{N}_{2} \mathrm{O}$ (see Hastings et al., 2003, 2004). In this paper, we report the uncorrected results; the mass independence of ${ }^{17} \mathrm{O}$ relative to the $m / z, 45$ signal of $\mathrm{N}_{2} \mathrm{O}$ generated from $\mathrm{NO}_{3}^{-}$ deposition was reported to result in a mean lowering of the $\delta^{15} \mathrm{~N}$ values by approximately $-1.5 \%$ (Elliott et al., 2009; Wankel et al., 2010). As denitrifying bacteria convert both $\mathrm{NO}_{3}^{-}$and $\mathrm{NO}_{2}^{-}$to $\mathrm{N}_{2} \mathrm{O}$, the $\delta^{15} \mathrm{~N}$ values reported here represent the combined pools of $\mathrm{NO}_{2}^{-}$and $\mathrm{NO}_{3}^{-}$. The presence of $\mathrm{NO}_{2}^{-}$interferes with the analyses of $\delta^{18} \mathrm{O}-\mathrm{NO}_{3}^{-}$and may result in some errors (Casciotti et al., 2002; Casciotti et al., 2007). In a similar study of the dual isotopes of aerosol $\mathrm{NO}_{3}^{-}$, Wankel et al. (2010) found average corrections for $\mathrm{NO}_{2}^{-}$interferences to be $+3.3 \%$ for samples in which $\mathrm{NO}_{2}^{-}$concentrations were $3 \%$ of total $\mathrm{NO}_{3}^{-}$plus $\mathrm{NO}_{2}^{-}$. In our study, four rainwater samples contained more than $5 \mu \mathrm{mol} \mathrm{L} \mathrm{L}^{-1} \mathrm{NO}_{2}^{-}$, but $\mathrm{NO}_{2}^{-}$made up on average $1.6 \%$ of total $\mathrm{NO}_{3}^{-}$plus $\mathrm{NO}_{2}^{-}$for all the samples over the study period. Assuming that $\delta^{18} \mathrm{O}$ of $\mathrm{NO}_{2}^{-}$is the same as $\delta^{18} \mathrm{O}$ of water $\left(-15\right.$ to $+0 \%$ ), $\mathrm{NO}_{2}^{-}$ contributes $1.6 \%$ to $\left(\mathrm{NO}_{2}^{-}+\mathrm{NO}_{3}^{-}\right)$and we can apply the calibration curve for $\mathrm{NO}_{2}^{-}$with denitrifier reported by Casciotti et al. (2007), the $\mathrm{NO}_{2}^{-}$will drop the values of $\delta^{18} \mathrm{O}-\mathrm{NO}_{3}^{-}$by $1.1-1.3 \%$. Thus, it was a minor analytical artifact resulting from the presence of $\mathrm{NO}_{2}^{-}$in this study.

\subsection{Backward trajectories}

To analyze the impact of air mass transportation, 72hour backward trajectories were computed for all sample days using NOAA's Hybrid Single-Particle Lagrangian Integrated Trajectory (HYSPLIT) (http://ready.arl.noaa.gov/ HYSPLIT_traj.php) (Draxler and Rolph, 2010) at an altitude of $500 \mathrm{~m}$ a.g.l. In this case, terrain height, ambient temperature, rainfall and relative humidity were used with HYSPLIT to calculate the back trajectories. The time frame was chosen since the lifetime of $\mathrm{NO}_{\mathrm{x}}$ in the boundary layer is generally less than 2 days, with a longer lifetime expected in the winter than in the summer, and since $\mathrm{HNO}_{3}$ generally has a similar atmospheric lifetime of 1-2 days (Liang et al., 1998). The air mass sectors were categorized to be of continental origin (i.e., the mainland of China) or marine origin (e.g., from the South China Sea or the Philippine Sea), according to the starting point of air mass transportation (72 hours before arrival at Guangzhou). The air masses starting over southern Asian countries like Thailand and Vietnam were considered to be of marine origin in this study because they passed through the South China Sea.

\subsection{Calculations and statistical analysis}

Annual $\mathrm{N}$ load from precipitation is the sum of the product of concentration and water amount for each sampling period. In this paper, both arithmetic and volume-weighted means were presented for $\mathrm{NO}_{3}^{-}$concentration. For isotopic composition, in addition to arithmetic mean, $\mathrm{NO}_{3}^{-}$-flux-weighted mean was also presented because isotopic composition was determined not only by volume but also by concentration. One-way ANOVA was performed for concentration, $\delta^{15} \mathrm{~N}$, and $\delta^{18} \mathrm{O}$ of precipitation $\mathrm{NO}_{3}^{-}$in order to identify the differences between seasons and between air mass sources for each year. Two-way ANOVA was used to identify the significance between years, seasons, and air mass sources for the investigated variables across the study period. Correlation analysis with the two-tail significance test was used to examine the relationships between variables across the study period or in the individual year. All analyses were conducted using PASW Statistics 18.0 for Windows. Statistically significant differences were set at $P$ values $<0.05$ unless otherwise stated.

\section{Results}

\subsection{Precipitation $\mathrm{NO}_{3}^{-}$input}

For the 113 precipitation samples collected in Guangzhou City, $\mathrm{NO}_{3}^{-}$concentration ranged from 6 to $256 \mu \mathrm{mol} \mathrm{L}-1$, except for one rain event on 17 September 2008 that had an unusually high concentration $\left(406 \mu \mathrm{mol} \mathrm{L}^{-1}\right)$ (Fig. 2b). As the isotope results for this sample were not anomalous (Fig. 2c, d), we considered that there was no contamination and the data were included in the data analysis. Two-way ANOVA using year and season as main factors showed that $\mathrm{NO}_{3}^{-}$concentration was not significantly different between years (Table 1). Mean $\mathrm{NO}_{3}^{-}$concentration was higher during the cool season (October to March) than during the warm season (April to September) in 2008, but the reverse was true in 2009 (Table 2).

The amounts of precipitation were $2162 \mathrm{~mm}$ in 2008 and $1931 \mathrm{~mm}$ in 2009 , with $77 \%$ and $79 \%$ falling during the warm season (Fig. 2a, Table 2). The annual $\mathrm{NO}_{3}^{-}$input in precipitation was 16.0 and $18.5 \mathrm{~kg} \mathrm{Nha}^{-1}$ in the two study years, with $74 \%$ and $80 \%$ falling in the warm season (Table 2). Continental precipitation accounted for $38 \%$ and $31 \%$ of the annual precipitation amount in 2008 and 2009, 
Table 1. Ranges and means of concentration, $\delta^{15} \mathrm{~N}$, and $\delta^{18} \mathrm{O}$ of $\mathrm{NO}_{3}^{-}$in precipitation.

\begin{tabular}{|c|c|c|c|c|c|c|c|c|c|c|c|}
\hline & \multicolumn{3}{|c|}{$\mathrm{NO}_{3}^{-}$con. $\left(\mu \mathrm{mol} \mathrm{L}^{-1}\right)$} & \multicolumn{4}{|c|}{$\delta^{15} \mathrm{~N}-\mathrm{NO}_{3}^{-}(\% \circ)$} & \multirow[b]{2}{*}{ Range } & \multirow[b]{2}{*}{ Mean $^{\mathrm{a}}$} & \multicolumn{2}{|c|}{$\delta^{18} \mathrm{O}-\mathrm{NO}_{3}^{-}(\% o)$} \\
\hline & Range & Mean ${ }^{\mathrm{a}}$ & Mean $^{b}$ & Range & Mean $^{\mathrm{a}}$ & Mean $^{b}$ & Mean $^{\mathrm{c}}$ & & & Mean $^{b}$ & Mean $^{c}$ \\
\hline 2008 & 6 to 406 & 63 & 53 & -3.9 to +7.9 & +3.9 & +3.7 & +4.2 & +33.4 to +81.5 & +65.0 & +64.9 & +71.8 \\
\hline 2009 & 9 to 256 & 77 & 68 & -4.9 to +10.1 & +3.3 & +3.0 & +3.5 & +48.2 to +86.2 & +67.7 & +66.5 & +70.6 \\
\hline
\end{tabular}

a arithmetic mean.

$\mathrm{b}$ volume-weighted mean.

${ }^{\mathrm{c}} \mathrm{NO}_{3}^{-}$-flux-weighted mean.

Table 2. Seasonal comparison of concentration, $\delta^{15} \mathrm{~N}$, and $\delta^{18} \mathrm{O}$ of $\mathrm{NO}_{3}^{-}$in precipitation.

\begin{tabular}{llrrrrrr}
\hline Year & Season & $n$ & $\begin{array}{r}\text { Precipitation } \\
(\mathrm{mm})\end{array}$ & $\begin{array}{r}\mathrm{NO}_{3}^{-} \text {input } \\
\left(\mathrm{kg} \mathrm{Nha}^{-1} \mathrm{a}^{-1}\right)\end{array}$ & $\begin{array}{r}\mathrm{NO}_{3}^{-} \text {con. } \\
\left(\mu \mathrm{mol} \mathrm{L}{ }^{-1}\right)\end{array}$ & $\begin{array}{r}\delta^{15} \mathrm{~N}_{-\mathrm{NO}_{3}^{-}} \\
(\%)\end{array}$ & $\begin{array}{r}\delta^{18} \mathrm{O}_{-} \mathrm{NO}_{3}^{-} \\
(\%)\end{array}$ \\
\hline 2008 & Cool & 9 & 491 & 4.1 & $89.9(9$ to $181,19.6)$ & $+4.5(+0.3$ to $+7.5,0.7)$ & $+73.2(+53.3$ to $+81.2,3.2)$ \\
& Warm & 50 & 1670 & 11.9 & $57.7(6$ to $406,9.4)$ & $+3.8(-3.9$ to $+7.9,0.3)$ & $+63.5(+33.4$ to $+81.5,1.4)$ \\
& $P$ value & & & 0.18 & 0.41 & 0.01 \\
2009 & Cool & 11 & 411 & 3.7 & $67.6(19$ to $181,14.5)$ & $+0.7(-4.9$ to $+4.3,0.9)$ & $+73.0(+59.3$ to $+84.4,2.7)$ \\
& Warm & 43 & 1520 & 14.8 & $78.8(10$ to $256,9.1)$ & $+4.1(+0.5$ to $+10.1,0.3)$ & $+66.4(+47.2$ to $+86.2,1.5)$ \\
& $P$ value & & & & 0.57 & $<0.001$ & 0.05 \\
\hline
\end{tabular}

The $P$ values were obtained by one-way ANOVA performed for each study year. Range (minimum and maximum) and one standard error of mean are given in parentheses.

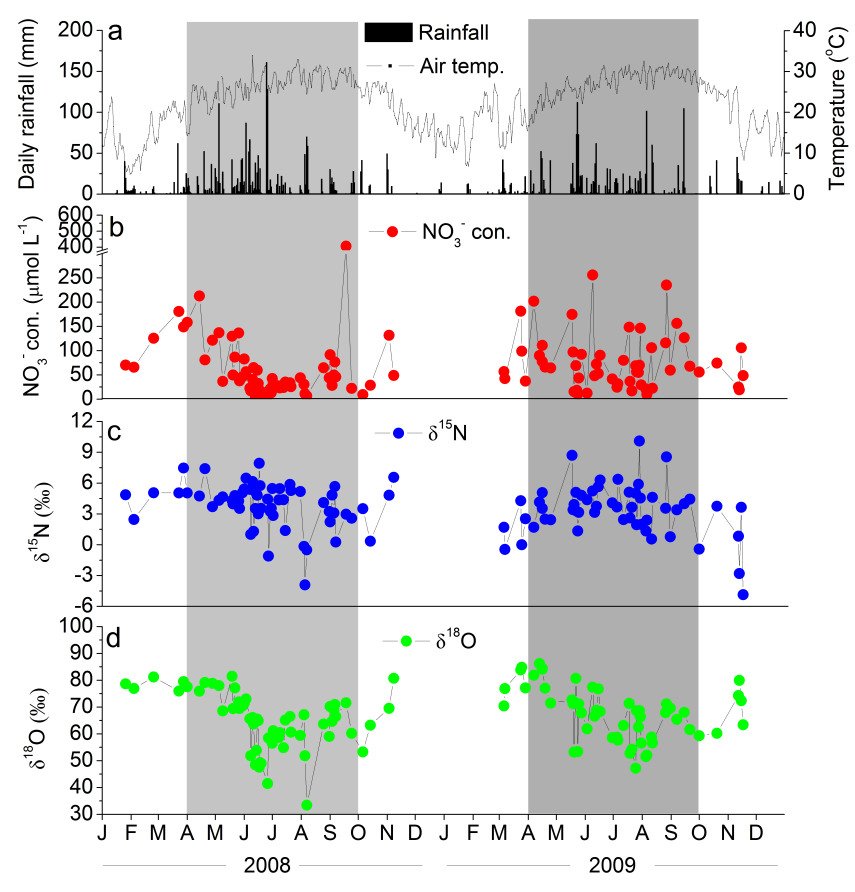

Fig. 2. Daily precipitation and mean air temperature (a), $\mathrm{NO}_{3}^{-}$concentration (b), $\delta^{15} \mathrm{~N}-\mathrm{NO}_{3}^{-}(\mathbf{c})$, and $\delta^{18} \mathrm{O}-\mathrm{NO}_{3}^{-}$(d) in precipitation from 2008 through 2009 in Guangzhou City. The shaded areas denote the warm seasons from April to September. respectively (Fig. 3), but brought proportionally more $\mathrm{NO}_{3}^{-}$ input (52\% and $41 \%$ of annual $\mathrm{NO}_{3}^{-}$input) due to the higher $\mathrm{NO}_{3}^{-}$concentration (Table 3 ).

\section{2 $\mathrm{N}$ isotopes of $\mathrm{NO}_{3}^{-}$}

Our measurements of $\delta^{15} \mathrm{~N}$ of precipitation $\mathrm{NO}_{3}^{-}$over the study period varied between $-4.9 \%$ and $+10.1 \%$, with annual mean values of $+3.9 \%$ in 2008 and $+3.3 \%$ in 2009 , respectively (Fig. 2c, Table 1). Positive $\delta^{15} \mathrm{~N}$ values were observed throughout 2008, but some negative values or near zero values were observed in the summer (Fig. 2c). However, the seasonal difference between the warm and cool seasons was not significant in that year (Table 2). There was also no significant difference in $\delta^{15} \mathrm{~N}$ values between continental and marine sources (Table 3). In 2009, $\delta^{15} \mathrm{~N}$ of $\mathrm{NO}_{3}^{-}$in the warm season was significantly higher than that in the cool season (Table 2).

\subsection{O isotopes of $\mathrm{NO}_{3}^{-}$}

The $\delta^{18} \mathrm{O}$ values of $\mathrm{NO}_{3}^{-}$ranged from +33.4 to $+86.2 \%$ o (Fig. 2d), with annual mean values of $+65.0 \%$ and $+67.7 \%$ in 2008 and 2009, respectively (Table 1). The $\mathrm{NO}_{3}^{-}$-fluxweighted $\delta^{15} \mathrm{~N}$ values were $+71.8 \%$ in 2008 and $+70.6 \%$ in 2009 (Table 1). The seasonal pattern of $\delta^{18} \mathrm{O}$ of $\mathrm{NO}_{3}^{-}$was clear, with values reaching a minimum in July or August. As a result, the $\delta^{18} \mathrm{O}$ values of $\mathrm{NO}_{3}^{-}$were significantly higher in the cool season than in the warm season for both study years 
Table 3. Sources comparison of concentration, $\delta^{15} \mathrm{~N}$, and $\delta^{18} \mathrm{O}$ of $\mathrm{NO}_{3}^{-}$in precipitation.

\begin{tabular}{|c|c|c|c|c|c|c|c|}
\hline Year & Season & $n$ & $\begin{array}{r}\text { Precipitation } \\
(\mathrm{mm})\end{array}$ & $\begin{array}{r}\mathrm{NO}_{3}^{-} \text {input } \\
\left(\mathrm{kg} \mathrm{Nha}^{-1} \mathrm{a}^{-1}\right)\end{array}$ & $\begin{array}{r}\mathrm{NO}_{3}^{-} \text {con. } \\
\left(\mu \mathrm{mol} \mathrm{L} \mathrm{L}^{-1}\right)\end{array}$ & $\begin{array}{r}\delta^{15} \mathrm{~N}-\mathrm{NO}_{3}^{-} \\
(\%)\end{array}$ & $\begin{array}{r}\delta^{18} \mathrm{O}-\mathrm{NO}_{3}^{-} \\
(\%)\end{array}$ \\
\hline \multirow[t]{3}{*}{2008} & Continental & 21 & 824 & 8.4 & $95.2(9$ to $406,19.0)$ & $+3.4(-3.9$ to $+7.4,0.6)$ & $+71.6(+51.8$ to $+81.5,1.9)$ \\
\hline & Marine & 38 & 1337 & 7.6 & 44.5 (6 to $212,6.9)$ & $+4.2(-1.1$ to $+7.9,0.3)$ & $+61.3(+33.4$ to $+79.5,1.6)$ \\
\hline & $P$ value & & & & 0.004 & 0.22 & $<0.001$ \\
\hline \multirow[t]{3}{*}{2009} & Continental & 19 & 589 & 8.3 & 83.1 (12 to $202,13.0)$ & $+1.9(-4.9$ to $+8.7,0.7)$ & $+71.6(+58.8$ to $+84.8,1.9)$ \\
\hline & Marine & 35 & 1342 & 12.1 & $73.0(10$ to $256,9.8)$ & $+4.1(+1.1$ to $+10.1,0.3)$ & $+65.5(+47.2$ to $+86.2,1.7)$ \\
\hline & $P$ value & & & & 0.53 & 0.002 & 0.06 \\
\hline
\end{tabular}

The $P$ values were obtained by one-way ANOVA performed for each study year. Range (minimum and maximum) and one standard error of mean are given in parentheses.
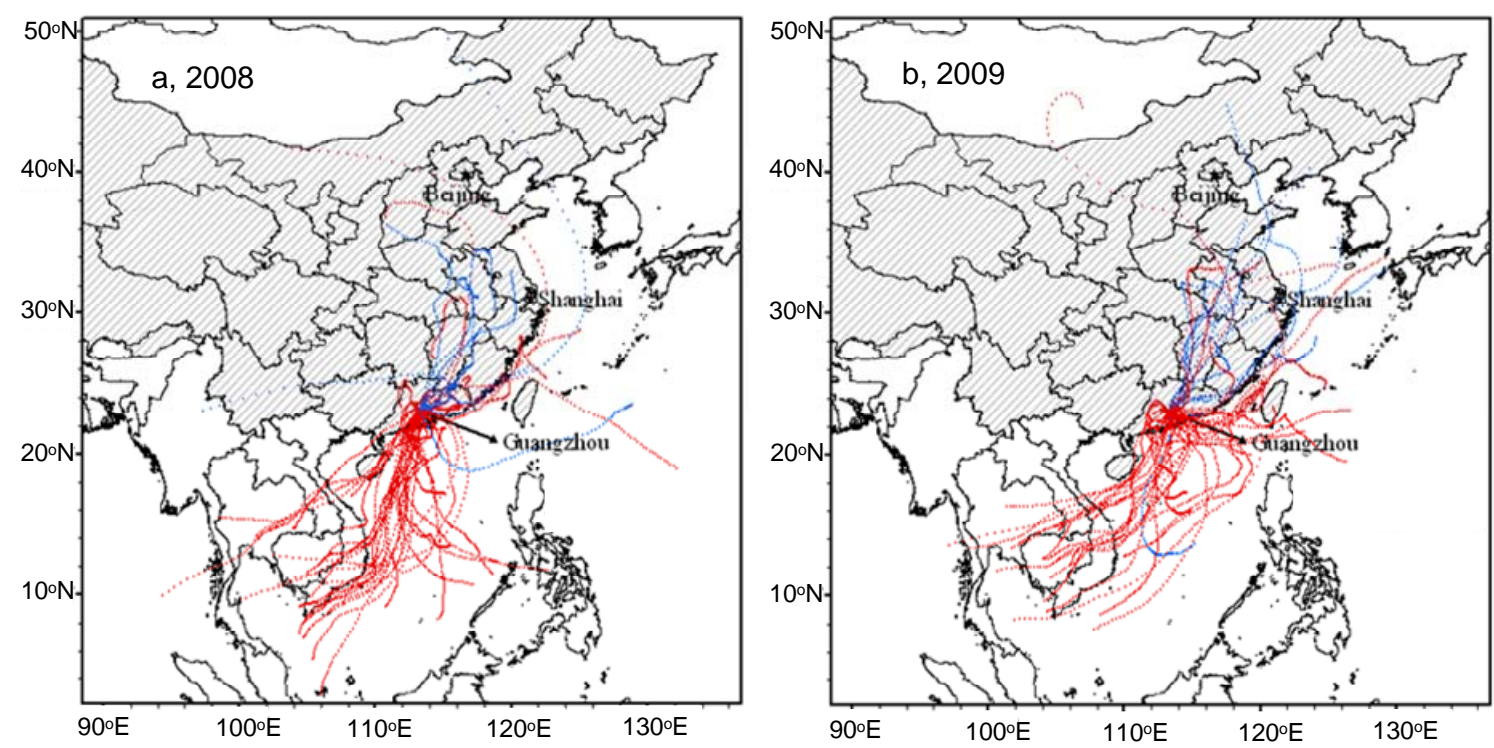

Fig. 3. 72-hour air mass backward trajectories for all sampling days in Guangzhou City, based on NOAA HYSPLIT model back trajectories. Lines in blue denote air mass trajectories occurring in the cool season and those in red denote trajectories in the warm season.

(Fig. 2d, Table 2). The continental source precipitation had higher $\delta^{18} \mathrm{O}$ of $\mathrm{NO}_{3}^{-}$than the marine source precipitation; the continental source precipitation mainly occurred in the cool season that had shorter daytime (Fig. 3).

\section{Discussion}

\subsection{Nitrogen deposition}

At our study site, $\mathrm{NH}_{4}^{+}$contributed an additional $14.9 \mathrm{~kg} \mathrm{Nha}^{-1} \mathrm{a}^{-1}$ in 2008 and $21.8 \mathrm{~kg} \mathrm{Nha}^{-1} \mathrm{a}^{-1}$ in 2009 to $\mathrm{N}$ deposition in precipitation, respectively (data not shown). Thus, the total inorganic $\mathrm{N}$ input was 30.9 and $40.3 \mathrm{~kg} \mathrm{Nha}^{-1} \mathrm{a}^{-1}$ in 2008 and 2009 , respectively. Compared with the small measured $\mathrm{N}$ deposition of $1.8-$ $3.2 \mathrm{~kg} \mathrm{Nha}^{-1} \mathrm{a}^{-1}$ in some remote areas in China (Liu et al., 1993) and of $0.9 \mathrm{~kg} \mathrm{Nha}^{-1} \mathrm{a}^{-1}$ in Hawaii (Carrillo et al., 2002), we suggest that such high bulk $\mathrm{N}$ deposition at the study site can be an important $\mathrm{N}$ input to terrestrial and aquatic ecosystems therein and that elevated $\mathrm{N}$ deposition is mainly caused by increased human activities associated with industrialization and urbanization.

\subsection{Seasonal pattern of $\mathrm{N}$ isotopes of $\mathrm{NO}_{3}^{-}$}

Our measurements of $\delta^{15} \mathrm{~N}$ of precipitation $\mathrm{NO}_{3}^{-}$over the study period varied between $-4.9 \%$ and $+10.1 \%$, with a total arithmetic mean of $+3.6 \%$ (Fig. 2, Table 1). These observed values fall well within the wide range of previously reported values for atmospheric $\mathrm{NO}_{3}^{-}$(Russell et al., 1998; Hastings et al., 2003; Heaton et al., 2004; Elliott et al., 2007, 2009; Kendall et al., 2007; Savarino et al., 2007; Morin et al., 2009) and are comparable to the results for urban or suburban sites in China (Zhang et al., 2008b; also see Supplement). Our results are higher than those in precipitation or particulate $\mathrm{NO}_{3}^{-}$in two rural sites in Hebei in northern China, most sites in Japan, over the Atlantic Ocean and the Pacific Ocean, and in the polar regions (Supplement), where most values are negative. Our measured values of $\delta^{15} \mathrm{~N}$ of precipitation $\mathrm{NO}_{3}^{-}$ 
were generally higher than the reports for wet deposition in the US (Elliott et al., 2007, 2009; Goodale et al., 2009 and references therein). For example, across 33 sites in the midwestern and northeastern US, $\delta^{15} \mathrm{~N}$ of wet $\mathrm{NO}_{3}^{-}$deposition ranged from -8.1 to $+3.2 \%$, with a mean of $-1.5 \%$ o (Elliott et al., 2007, Supplement). A wider range of $\delta^{15} \mathrm{~N}$ of atmospheric $\mathrm{NO}_{3}^{-}$was observed in Europe (Freyer, 1978, 1991; Yeatman et al., 2001; Widory, 2007, and Supplement). Cautions may be needed when comparing $\delta^{15} \mathrm{~N}$ data from different atmospheric matrices, because the $\delta^{15} \mathrm{~N}$ of aerosol $\mathrm{NO}_{3}^{-}$ is very different from that of rainwater $\mathrm{NO}_{3}^{-}$in some studies (e.g., aerosol nitrate $\delta^{15} \mathrm{~N}$ was $9 \%$ o higher than rainwater nitrate $\delta^{15} \mathrm{~N}$ in Jülich, a moderately polluted city of German; Freyer, 1991, Supplement) while is not in other studies (Baker et al., 2007; or see Morin et al., 2009).

Seasonality has been commonly reported for isotopic composition of atmospheric $\mathrm{NO}_{3}^{-}$(Hastings et al., 2003; Elliott et al., 2007, 2009; Morin et al., 2008; Wankel et al., 2010). The seasonal pattern of $\delta^{15} \mathrm{~N}$ seems to vary from site to site. In a study performed in the Arctic, temperature was found to be a major determinant of $\delta^{15} \mathrm{~N}-\mathrm{NO}_{3}^{-}$values in all seasons except spring when snowpack emissions are maximal (Morin et al., 2008). Temperature was also found to significantly influence $\delta^{15} \mathrm{~N}^{-\mathrm{NO}_{3}^{-}}$in both dry and wet depositions across the region of Ohio, New York, and Pennsylvania in the US, with lower values in summer months than in winter months (Elliott et al., 2009). By contrast, in Bermuda in the North Atlantic Ocean (Hastings et al., 2003) and in Eilat, Israel (Wankel et al., 2010), $\delta^{15} \mathrm{~N}$ of atmospheric $\mathrm{NO}_{3}^{-}$was significantly higher in the warmer season. The difference in pattern is likely to be a result of the shift in $\mathrm{NO}_{\mathrm{x}}$ sources for those studies. In the present study, $\delta^{15} \mathrm{~N}^{-\mathrm{NO}_{3}^{-}}$was correlated with temperature only in 2009 (Fig. 4b). The high

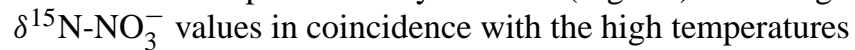
observed in 2009 (Table 2) might be caused by the high demand for fossil fuel because of the intense preparations for the 16th Asian Games (see below).

In the present study, we initially expected that the precipitation with a marine origin would have similar $\delta^{15} \mathrm{~N}$ values of $\mathrm{NO}_{3}^{-}$to those reported for the atmospheric matrices collected above oceans. The $\delta^{15} \mathrm{~N}$ values of atmospheric $\mathrm{NO}_{3}^{-}$were -7.1 to $-1.6 \%$ (average $-4 \%$ o) in the low latitude regions of the Atlantic Ocean (between $45^{\circ} \mathrm{S}$ and $45^{\circ} \mathrm{N}$ ) (Morin et al., 2009). Baker et al. (2007) reported that $\delta^{15} \mathrm{~N}$ of atmospheric $\mathrm{NO}_{3}^{-}$from those areas ranged from -11 to $+2.8 \%$ o and averaged $-3 \%$. A similar range $(-14$ to $+1.8 \%$, average $-2.1 \%$ in the warm season and $-5.9 \%$ in the cool season) was observed for $\delta^{15} \mathrm{~N}$ of rain $\mathrm{NO}_{3}^{-}$in Bermuda in the North Atlantic Ocean (Hastings et al., 2003). The $\delta^{15} \mathrm{~N}$ values of precipitation $\mathrm{NO}_{3}^{-}$in two Hawaiian islands in the Pacific Ocean were reported to range narrowly from -3.8 to $+2.4 \%$ (average, $-0.03 \%$ and $-2.9 \%$, respectively) (Carrillo et al., 2002). We did observe a few negative values as previously reported during storms in the summer of 2008, but
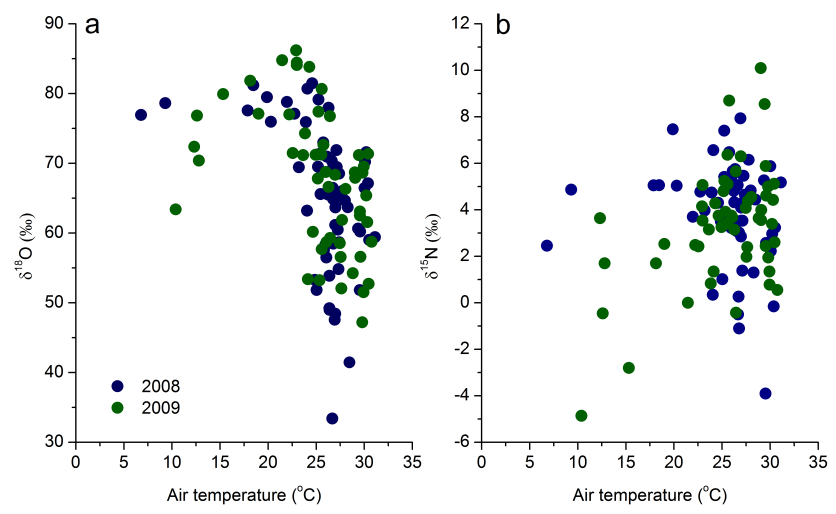

Fig. 4. $\delta^{18} \mathrm{O}-\mathrm{NO}_{3}^{-}$(a) and $\delta^{15} \mathrm{~N}-\mathrm{NO}_{3}^{-}$(b) vs. mean air temperature three days prior to sampling over the study period. For panel (a), $R^{2}=-0.21, P<0.001$ in 2008 ; and $R^{2}=-0.20, P=0.001$ in 2009. For panel (b), $R^{2}=-0.03, P=0.222$ in 2008; and $R^{2}=$ $0.24, P<0.001$ in 2009 .

most values were positive during the study period (Fig. 2c). Furthermore, we found that the averaged $\delta^{15} \mathrm{~N}$ values were lower for precipitation from the continent than for that from the sea, particularly in 2009 (Table 3). Over the two study years, $\delta^{15} \mathrm{~N}$ was $+4.1 \%$ in precipitation from the sea, and was significantly $(P=0.017)$ higher than $+3.1 \%$ from the continent. The mean $\mathrm{NO}_{3}^{-}$concentration in the marine source precipitation (on average 44 and $73 \mu \mathrm{mol} \mathrm{L}^{-1}$ in 2008 and 2009, respectively, Table 3) was far higher than the annual means (0.5 to $2 \mu \mathrm{mol} \mathrm{L}{ }^{-1}$ ) in Hawaii (Carrillo et al., 2002). The high $\delta^{15} \mathrm{~N}$ values and concentrations of $\mathrm{NO}_{3}^{-}$in the precipitation of marine origin in this study indicate the influence of anthropogenic $\mathrm{NO}_{\mathrm{x}}$ emissions (with relatively high ${ }^{15} \mathrm{~N} /{ }^{14} \mathrm{~N}$ ratio) locally and from neighboring large cities to the south of Guangzhou (e.g., Hong Kong, Shenzhen, Dongguan, and Zhongshan) on the temporal pattern of $\delta^{15} \mathrm{~N}$ of $\mathrm{NO}_{3}^{-}$.

The $\delta^{15} \mathrm{~N}$ values of precipitation $\mathrm{NO}_{3}^{-}$were obviously higher in the summer than in other seasons in 2009, and the pattern was different from that in 2008. Higher $\delta^{15} \mathrm{~N}$ values in atmospheric $\mathrm{NO}_{3}^{-}$were often found in winter than in summer (e.g., Jülich, Germany, Freyer, 1978; 1991; Pretoria in South Africa, Heaton, 1987). These higher $\delta^{15} \mathrm{~N}$ values in winter have been attributed to $\mathrm{N}$ isotope exchange between $\mathrm{NO}$ and $\mathrm{NO}_{2}$, which enriches ${ }^{15} \mathrm{~N}$ in the more oxidized form. This $\mathrm{N}$ isotope exchange occurs more likely in the seasons when the $\mathrm{NO}_{2} / \mathrm{NO}_{\mathrm{x}}$ ratio and $\mathrm{O}_{3}$ concentration is low, as demonstrated in the winter time at Jülich (Freyer et al., 1993). In the case of our study site in Guangzhou city, we found that in 2009 monthly mean $\mathrm{NO}_{2} / \mathrm{NO}_{\mathrm{x}}$ and $\mathrm{O}_{3}$ concentration were lower in the summer than in the winter (Fig. 5). Thus low $\mathrm{NO}_{2} / \mathrm{NO}_{\mathrm{x}}$ and $\mathrm{NO}_{\mathrm{x}} / \mathrm{O}_{3}$ ratios (favoring $\mathrm{N}$ isotopic exchange) in the summer of 2009 may partly explain relatively higher $\delta^{15} \mathrm{~N}$ in precipitation $\mathrm{NO}_{3}^{-}$during the same time period (Fig. 2c). We don't have NO data for 2008. But we can infer that $\mathrm{NO}_{2} / \mathrm{NO}_{\mathrm{x}}$ ratio in 2008 will have a 


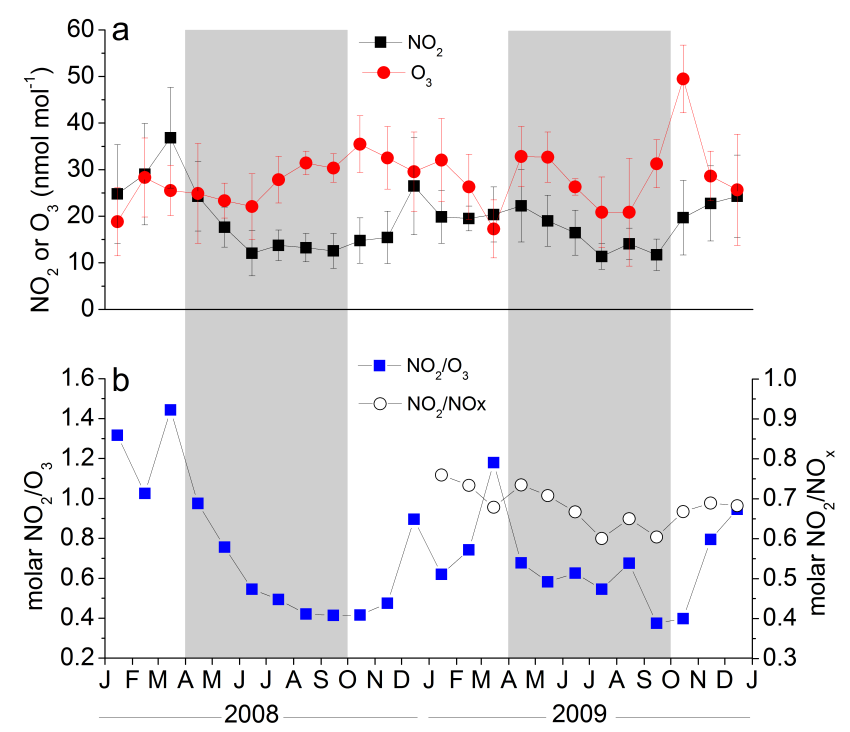

Fig. 5. Seasonal changes in $\mathrm{NO}_{2}$ and $\mathrm{O}_{3}$ concentrations (a), monthly mean of three monitoring sites), molar ratios of $\mathrm{NO}_{2} / \mathrm{O}_{3}$ and $\mathrm{NO}_{2} / \mathrm{NO}_{\mathrm{x}}(\mathbf{b})$ during the study course in Guangzhou City. The shaded areas denote the warm seasons from April to September. Data is available at: http://www-app.gdepb.gov.cn/EQPublish/raqi. aspx).

similar seasonal pattern as that in 2009 , since $\mathrm{NO}_{2}$ concentration was positively correlated to NO concentration in 2009 ( $P<0.001$, data not shown). However, in 2008, we found higher $\delta^{15} \mathrm{~N}$ values in precipitation $\mathrm{NO}_{3}^{-}$in the winter, although the seasonal pattern was not as distinct as in 2009. So $\mathrm{N}$ isotopic exchange can not fully explain the observation in Guangzhou city.

We suggest that the difference in seasonal pattern of $\delta^{15} \mathrm{~N}$ of precipitation $\mathrm{NO}_{3}^{-}$between 2008 and 2009 may have mainly resulted from two factors. One is the different precipitation regime. The study city Guangzhou, is located in the center of a large economic area (the Pearl River Delta), which consists of many big cities, like Guangzhou, Shenzhen, Zhuhai and Dongguan. The Pearl River Delta has an area of $4.2 \times 10^{4} \mathrm{~km}^{2}$, where there are more than 0.4 billion habitants. During the strong precipitation events, especially typhoons, there is obvious air mass transportation from the east to the west in warm seasons (Fig. 3). There was a larger amount of precipitation in 2008 than in 2009, and precipitation was more concentrated in May and June (Fig. 2a), which thus might have blown N-bearing pollutants over the study city away and replaced the atmosphere with relatively clean air masses from the sea (Fig. 3). This is supported by the lower $\mathrm{N}$ input in precipitation in 2008 than in 2009 (Table 2) and the distinct seasonal fluctuation of precipitation $\mathrm{NO}_{3}^{-}$in 2008 (Fig. 2b). The other is human activities. In 2008, many manufacturers in Guangzhou and the Pearl River Delta were severely affected by the global financial crisis starting from 2007. Nevertheless, the economy recovered and was stimu-
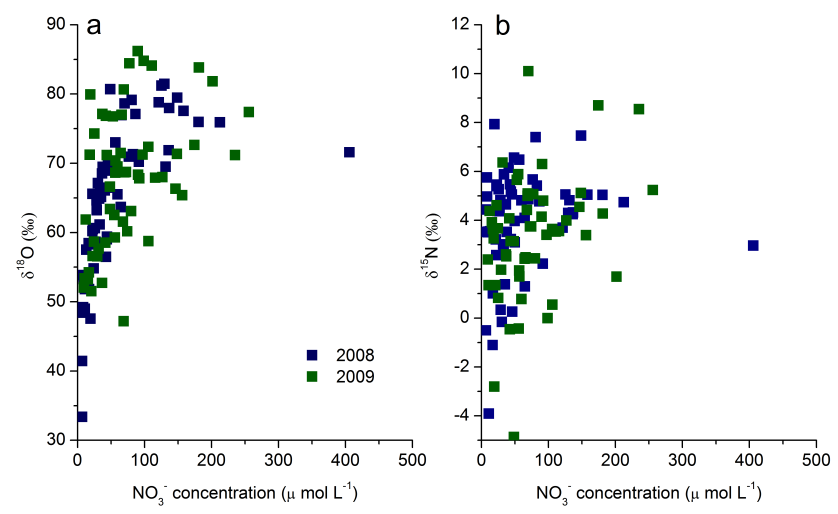

Fig. 6. $\delta^{18} \mathrm{O}-\mathrm{NO}_{3}^{-}$(a) and $\delta^{15} \mathrm{~N}-\mathrm{NO}_{3}^{-}$(b) vs. $\mathrm{NO}_{3}^{-}$concentration in precipitation over the study period. For panel (a), $R^{2}=0.21$, $P<0.001$ in 2008; and $R^{2}=0.20, P=0.001$ in 2009. For panel (b), $R^{2}=-0.03, P=0.22$ in 2008 ; and $R^{2}=0.24, P<0.001$ in 2009 .

lated by the intensive preparations for the 16th Asian Games. The gross domestic product of Guangzhou City is $11.5 \%$ higher in 2009 than in 2008 (http://www.gemc.gov.cn/). In the present study, we observed significant correlations between $\delta^{15} \mathrm{~N}$ of $\mathrm{NO}_{3}^{-}$and concentrations of $\mathrm{NO}_{3}^{-}$(Fig. 6) and $\mathrm{SO}_{4}^{2-}$ (data not shown) in 2009, indicating the importance of air pollution in controlling $\delta^{15} \mathrm{~N}$ of precipitation $\mathrm{NO}_{3}^{-}$. Such strong correlations have also been noted for precipitation across 33 sites in midwestern and northeastern US (Elliott et al., 2007).

\subsection{Partitioning of $\mathrm{NO}_{\mathrm{x}}$ sources using $\mathrm{N}$ isotopes of $\mathrm{NO}_{3}^{-}$}

The $\delta^{15} \mathrm{~N}$ values of fuel $\mathrm{NO}_{\mathrm{x}}$ (e.g., from coal combustion) have been reported to be much more positive than those from natural sources, although a few studies showed negative values (Supplement). Furthermore, the fuel $\mathrm{NO}_{\mathrm{x}}$ are generally more enriched in ${ }^{15} \mathrm{~N}$ than the thermal $\mathrm{NO}_{\mathrm{x}}$ (Supplement). Based on the positive $\delta^{15} \mathrm{~N}$ values in most of the samples in our study, we speculate that the source of $\mathrm{NO}_{\mathrm{x}}$ is predominantly fossil fuel combustion in Guangzhou City, particularly coal combustion, because coal is commonly used to generate electricity in this economically developing zone. This view is further supported by a strong correlation of $\mathrm{NO}_{3}^{-}$concentration with $\mathrm{SO}_{4}^{2-}$ concentration in precipitation (Fig. 7), which suggests that $\mathrm{NO}_{\mathrm{x}}$ and $\mathrm{SO}_{2}$ may be produced simultaneously through S-containing coal combustion as vehicles emit negligible $\mathrm{SO}_{2}$ relative to coal combustion sources. A bottom-up inventory revealed that in China, more than $70 \%$ of the total $\mathrm{NO}_{\mathrm{x}}$ emission was from coal combustion (Tian et al., 2001).

Assuming that the precipitation $\mathrm{NO}_{3}^{-}$at our study site has only two sources, anthropogenic (assuming that $\mathrm{NO}_{\mathrm{x}}$ emissions principally originate from fossil fuel combustion) and natural (e.g., lightning and biogenic emissions), and 
that $\delta^{15} \mathrm{~N}_{\text {anthropogenic }}$ is $+10.1 \%$ (the maximum value of the study period) and $\delta^{15} \mathrm{~N}_{\text {natural }}$ is $-4.9 \%$ (the minimum value), we can attempt to separate the relative contribution of each source to the total $\mathrm{NO}_{3}^{-}$deposition for each sampling event and each year using a simple two-end-member model. Calculations show that on average $59 \%$ and $55 \%$ of precipitation $\mathrm{NO}_{3}^{-}$in 2008 and 2009, respectively, were from an anthropogenic source. This estimate is tentative because the variation of $\delta^{15} \mathrm{~N}$ of $\mathrm{NO}_{3}^{-}$are also influenced by the ${ }^{15} \mathrm{~N}$ partition within $\mathrm{NO}_{\mathrm{x}}$ and/or the isotopic fractionation arising from the conversion of $\mathrm{NO}_{2}$ to $\mathrm{NO}_{3}^{-}$or the transport of atmospheric $\mathrm{NO}_{3}^{-}$itself (Morin et al., 2009), which have not been considered in the above estimation. It is difficult to assess these uncertainties with the present data. However, such an estimate can provide an insight into the change in the contribution of anthropogenic emissions with time (Hastings et al., 2003, 2009).

The anthropogenic contribution to total $\mathrm{NO}_{3}^{-}$deposition discussed above is likely underestimated because such a high $\mathrm{NO}_{3}^{-}$deposition in the study city must directly result from increased anthropogenic emissions due to energy use from local cities in the Pearl River Delta where our study site is located and/or from inland cities in China. A bottom-up inventory conducted in the Pearl River Delta showed that $46 \%$ and $41 \%$ of the total $\mathrm{NO}_{\mathrm{x}}$ emissions in 2006 were from power plant and mobile sources, respectively, and that the industry was responsible for an additional 12\% (Zheng et al., 2009). In that inventory, however, the contributions of biogenic sources and lightning were not included (Zheng et al., 2009). A top-down inventory constructed using an inversion approach with a global 3-D chemical transport model (GEOS-Chem) showed that fossil fuel and biofuel combustion accounted for $77 \%$ and $12 \%$ of the total $\mathrm{NO}_{\mathrm{x}}$ emissions over east China, respectively, and the rest (11\%) was accounted for by biomass burning, microbial sources, and lightning (Wang et al., 2007). Several factors may lead to the underestimation on anthropogenic contribution to $\mathrm{NO}_{\mathrm{x}}$ emission. First, the assumed $\delta^{15} \mathrm{~N}_{\text {anthropogenic value in this }}$ study may be higher than the actual one, as the thermal $\mathrm{NO}_{\mathrm{x}}$ exhibits negative values in $\delta^{15} \mathrm{~N}$ and the $\delta^{15} \mathrm{~N}$ values of vehicular $\mathrm{NO}_{\mathrm{x}}$ are reported around $+5 \%$ o (see the introduction or Supplement). Secondly, the $\delta^{15} \mathrm{~N}_{\text {natural value used in the }}$ estimation may be higher than the actual value, although it is very similar to the lowest record of $-3.8 \%$ in rain $\mathrm{NO}_{3}^{-}$ in Hawaii (Carrillo et al., 2002). Thirdly, the ${ }^{15} \mathrm{~N}$ signature of thermal $\mathrm{NO}_{\mathrm{x}}$ (largely consisted of vehicle exhaust) might have failed to be recorded by our precipitation samples, for ground-level emissions of tailpipe $\mathrm{NO}_{\mathrm{x}}$ relative to smokestack $\mathrm{NO}_{\mathrm{x}}$ emissions higher in the troposphere may result in different reaction pathways and scavenging efficiencies for vehicle $\mathrm{NO}_{\mathrm{x}}$ (Elliott et al., 2007).

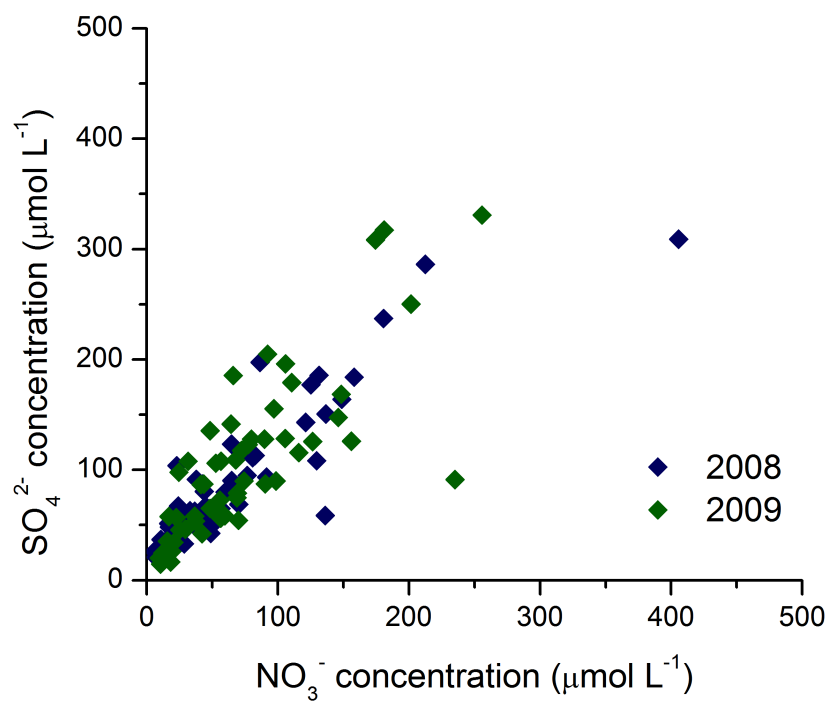

Fig. 7. $\mathrm{NO}_{3}^{-}$concentration vs. $\mathrm{SO}_{4}^{2-}$ concentration in precipitation collected in 2008 to 2009 in Guangzhou City. $R^{2}=0.80, P<0.001$ in $2008 ; R^{2}=0.77, P<0.001$ in 2009 .

\subsection{Oxygen isotopes of $\mathrm{NO}_{3}^{-}$}

In this study, $\delta^{18} \mathrm{O}$ of precipitation $\mathrm{NO}_{3}^{-}$ranged from +33.4 to $+86.2 \%$, with an average of $+66.3 \%$ (Table 1 ). These values lie within the broad range of previous reports (Hastings et al., 2003, 2007; Elliott et al., 2007, 2009; Kendall et al., 2007; Morin et al., 2008, 2009; Tsunogai et al., 2010). However, the annual mean values of $\delta^{18} \mathrm{O}$ were lower than those of previous studies performed in high latitude and polar regions and our data fell in the low end of the reported range of the world.

The $\delta^{18} \mathrm{O}$ values of atmospheric $\mathrm{NO}_{3}^{-}$varied from +59.6 to $+114.4 \%$ in coastal Antarctica $\left(66^{\circ} 40^{\prime} \mathrm{S}, 140^{\circ} 01^{\prime} \mathrm{E}\right)$, with averages of $+63.2 \%$ in January to March, $+79.1 \%$ o in March to mid-July, $+103.9 \%$ in mid-July to September, and $+77.2 \%$ in October to December (Savarino et al., 2007). In nonpolar regions, Morin et al. (2009) observed a large range of $\delta^{18} \mathrm{O}$ values for atmospheric $\mathrm{NO}_{3}^{-}(+50$ to $+90 \%$ o $)$ in their study for the Altantic Ocean boundary layer from $65^{\circ} \mathrm{S}$ to $79^{\circ}$ N. Similarly, a range of +67 to $+100 \%$ o for precipitation $\mathrm{NO}_{3}^{-}$was observed in the island of Rishiri, northern Japan $\left(45.2^{\circ} \mathrm{N}\right.$, Tsunogai et al., 2010). Our results are slightly lower than those reported for Bermuda, which has a low latitude $\left(32.27^{\circ} \mathrm{N}, 64.87^{\circ} \mathrm{W}\right)$, where the $\delta^{18} \mathrm{O}$ values of precipitation $\mathrm{NO}_{3}^{-}$ranged from +60.3 to $+86.5 \%$, averaging $+68.6 \%$ in the warm season and $+76.9 \%$ in the cool season (Hastings et al., 2003), across the region of Ohio, New York, and Pennsylvania in the US where the $\delta^{18} \mathrm{O}$ values of $\mathrm{NO}_{3}^{-}$ranged from +45.2 to $+94.0 \%$ with mean values of $+77.4 \%$ o for $\mathrm{HNO}_{3}$ vapor and $+75.2 \%$ o for particulate $\mathrm{NO}_{3}^{-}$ (Elliott et al., 2009), and the Gulf of Aqaba in Israel where aerosol $\mathrm{NO}_{3}^{-}$ranged from +66.1 to $+85.3 \%$, with $+77.3 \%$ o 
in the summer and $+80.5 \%$ o in the winter (Wankel et al., 2010). The relatively low $\delta^{18} \mathrm{O}$ values in our study suggest the importance of the $\mathrm{OH}$ radical pathway in forming atmospheric $\mathrm{NO}_{3}^{-}$(through which $\mathrm{O}_{3}$ donates fewer $\mathrm{O}$ atoms to $\mathrm{NO}_{3}^{-}$than that through the $\mathrm{N}_{2} \mathrm{O}_{5}$ pathway; see Introduction), due in part to the long summer time and maybe the strong solar radiation. This interpretation is consistent with the results obtained based on a global model of $\Delta^{17} \mathrm{O}$ (the oxygen isotopic anomaly which is quantified as $\delta^{17} \mathrm{O}-0.52 \times \delta^{18} \mathrm{O}$ ) of atmospheric $\mathrm{NO}_{3}^{-} ; \mathrm{NO}_{3}^{-}$production via the $\mathrm{OH}$ pathway predominates (up to $87 \%$ ) in the tropics where $\mathrm{OH}$ concentration is the highest (Alexander et al., 2009).

The seasonality of these $\mathrm{NO}_{3}^{-}$formation pathways is a function of both temperature $\left(\mathrm{N}_{2} \mathrm{O}_{5}\right.$ is thermally decomposed) and solar radiation ( $\mathrm{OH}$ is photolytically produced). This chemical fingerprint of $\delta^{18} \mathrm{O}$ of $\mathrm{NO}_{3}^{-}$by $\mathrm{O}_{3}$ has been used to characterize the predominance of multiple chemical pathways (Savarino et al., 2007; Jarvis et al., 2008; Morin et al., 2008). In the present study, the warm season averages of $+63.5 \%$ and $+66.4 \%$ in 2008 and 2009 , respectively, were significantly lower than the cool season averages of $73.2 \%$ o and $73.0 \%$ (Table 2). As expected, temperature controls $\delta^{18} \mathrm{O}$ of $\mathrm{NO}_{3}^{-}$(Fig. 4a). When the air temperature was below $23^{\circ} \mathrm{C}, \delta^{18} \mathrm{O}$ of $\mathrm{NO}_{3}^{-}$was higher than $70 \%$. However, a large variation was noted when the temperature was above $23^{\circ} \mathrm{C}$. We found no relationship between $\delta^{18} \mathrm{O}$ and solar radiation (data not shown). We initially expected that the seasonal fluctuation would be small due to the relatively equal distribution of daytime and nighttime within a day throughout the year as compared to high latitude and polar regions that have much longer nighttime in winter. However, we found that at our study site, the difference in seasonal maximum and minimum $\delta^{18} \mathrm{O}$ is as much as $53 \%$, and this difference is even greater than the seasonal difference of about 30\% in coastal Antarctica when the austral later winter and early spring was excluded because during that period $\mathrm{NO}_{3}^{-}$sedimentation from polar stratospheric clouds results in particular high $\delta^{18} \mathrm{O}$ values which is very different from the situation in other seasons (Savarino et al., 2007) and greater than those in middle and high latitude areas (Hastings et al., 2003; Elliott et al., 2009; Tsunogai et al., 2010). The reasons remain unclear and further research is required.

Using the minimum and maximum of $\delta^{18} \mathrm{O}$ reported for $\mathrm{O}_{3}$ (+90 to $+122 \%$, Krankowsky et al., 1995 ; Johnston and Thiemens, 1997) and $\mathrm{OH}$ (typically between $-15 \%$ o to $0 \%$ o over the Asian continent, see maps from the Global Network of Isotopes in Precipitation, International Atomic Energy Agency, available at: http://isohis.iaea.org), one can expect that the $\delta^{18} \mathrm{O}$ value of atmospheric $\mathrm{NO}_{3}^{-}$will fall between $+55 \%$ o (assuming $2 / 3$ oxygen atoms from $\mathrm{O}_{3}$ and $1 / 3$ from $\mathrm{OH}$ ) and $+102 \%$ o (assuming $5 / 6$ oxygen atoms from $\mathrm{O}_{3}$ and $1 / 6$ from $\mathrm{OH}$ ) (see Hastings et al., 2003).

In this study, we observed that 18 samples $(16 \%$ of the total samples) had $\delta^{18} \mathrm{O}$ values being lower than $+55 \%$. The lowest was $+33 \%$ o (Fig. 2d), which, so far, is among the lowest ever reported in the world. One may argue that the presence of $\mathrm{NO}_{2}^{-}$interferes with the analyses of $\delta^{18} \mathrm{O}_{-} \mathrm{NO}_{3}^{-}$and may result in some errors (Casciotti et al., 2002; Casciotti et al., 2007, also see the method section). After the correction of $\mathrm{NO}_{2}^{-}$interference $(+0 \%$ o to $+5.8 \%$ ) $)$, we still find that in this study there are 12 values being lower than the expected minimum.

As stated previously, the $\mathrm{OH}$ pathway and the $\mathrm{N}_{2} \mathrm{O}_{5}$ pathway are the main channels for atmospheric $\mathrm{NO}_{3}^{-}$formation. Globally, $76 \%$ and $18 \%$ of annual inorganic $\mathrm{NO}_{3}^{-}$are formed via the $\mathrm{OH}$ pathway and the $\mathrm{N}_{2} \mathrm{O}_{5}$ pathway, respectively, based on a global model of $\Delta^{17} \mathrm{O}$ of atmospheric $\mathrm{NO}_{3}^{-}$(Alexander et al., 2009). At night, $\mathrm{NO}_{3}$ can also react with dimethylsulfide (DMS) or hydrocarbons (HC), termed the $\mathrm{NO}_{3}^{-}+\mathrm{DMS} / \mathrm{HC}$ pathway here; this pathway accounts for $4 \%$ of the annual inorganic $\mathrm{NO}_{3}^{-}$on the global scale based on a global model of $\Delta^{17} \mathrm{O}$ of atmospheric $\mathrm{NO}_{3}^{-}$ (Alexander et al., 2009). Atmospheric $\mathrm{NO}_{3}^{-}$induced via the $\mathrm{NO}_{3}^{-}+$DMS/HC pathway will probably have higher $\delta^{18} \mathrm{O}$ values than those induced via the $\mathrm{OH}$ pathway and the $\mathrm{N}_{2} \mathrm{O}_{5}$ pathway due to its more involvement with $\mathrm{O}_{3}$ during formation (Alexander et al., 2009). In addition, $\mathrm{NO}_{\mathrm{x}}$ can interact with halogen oxides, such as bromine oxide $(\mathrm{BrO})$, to form bromine nitrate $\left(\mathrm{BrONO}_{2}\right)$ and this in turn can be hydrolyzed to $\mathrm{NO}_{3}$ (Morin et al., 2008; Alexander et al., 2009). The atmospheric $\mathrm{NO}_{3}^{-}$induced by this pathway will have a $\delta^{18} \mathrm{O}$ value similar to that of $\mathrm{O}_{3}$, for $\mathrm{BrO}$ is expected to have a large $\delta^{18} \mathrm{O}$ value due to the involvement of $\mathrm{O}_{3}$ in $\mathrm{BrO}$ formation. Thus, the last two pathways cannot explain the $\delta^{18} \mathrm{O}$ values of $\mathrm{NO}_{3}^{-}$below $+55 \%$ in our study either. One possibility for the lower than usual $\delta^{18} \mathrm{O}$ values of $\mathrm{NO}_{3}^{-}$is oxygen isotopic fractionation, which can induce large variations in $\delta^{18} \mathrm{O}$ values between the reactants and the products (see e.g., Chakraborty and Chakraborty, 2003).

The other possible explanation is the reaction of NO with peroxy radicals $\left(\mathrm{HO}_{2}\right.$ and its organic homologues $\mathrm{RO}_{2}$ ), which can compete with $\mathrm{O}_{3}$ to convert $\mathrm{NO}$ into $\mathrm{NO}_{2}$ (Reactions R7 and R8).

$\mathrm{OH}+\mathrm{CO}+\mathrm{O}_{2} \rightarrow \mathrm{CO}_{2}+\mathrm{HO}_{2}$

$\mathrm{HO}_{2}+\mathrm{NO} \rightarrow \mathrm{NO}_{2}+\mathrm{OH}$

The $\delta^{18} \mathrm{O}$ of peroxy radicals is expected to be much lower than that of $\mathrm{O}_{3}$ as the $\mathrm{O}$ atoms should come from atmospheric $\mathrm{O}_{2}\left(\delta^{18} \mathrm{O}=+23.9 \%\right.$, see Barkan and Luz, 2003). If we assume that $\mathrm{NO}$ exchanges $\mathrm{O}$ atom to form $\mathrm{NO}_{2}$ completely with peroxy radicals instead of $\mathrm{O}_{3}$, then we can expect that the minimum $\delta^{18} \mathrm{O}$ value of formed $\mathrm{NO}_{3}^{-}$will be $+11 \%$ followed by the reaction $\mathrm{R} 3$ (up to $2 / 3$ of the $\mathrm{O}$ atoms from atmospheric $\mathrm{O}_{2}$ and $1 / 3$ from $\mathrm{OH}$ ) and $+28 \%$ followed by the reactions R4 to R6 (up to $4 / 6$ of the $\mathrm{O}$ atom from atmospheric $\mathrm{O}_{2}, 1 / 6$ from $\mathrm{O}_{3}$ and $1 / 6 \mathrm{O}$ from $\mathrm{H}_{2} \mathrm{O}$ ), respectively. We observed the lowest value of $+33 \%$ in the study city, which is 
just slightly higher than the calculated minimum of $+28 \%$, suggesting that peroxy radicals may be an important oxidant in the conversion of $\mathrm{NO}$ to $\mathrm{NO}_{2}$ and thereby $\mathrm{NO}_{3}^{-}$formation in the atmosphere.

Peroxy radicals are important intermediates in atmospheric photo-oxidant formation. They arise from the oxidation of carbon monoxide (CO) and volatile organic compounds (VOC) by $\mathrm{OH}$ radicals, $\mathrm{NO}_{3}$ radicals, halogen atoms, and $\mathrm{O}_{3}$. This phenomenon very likely occurs in our study city that has complex air pollution, because $\mathrm{CO}$ is also a major air pollutant (Hua et al., 2008; Liu et al., 2008; Zhang et al., 2008a; Shao et al., 2009).

\section{Conclusions}

We demonstrated the seasonal variations of $\mathrm{N}$ and $\mathrm{O}$ isotopic composition of precipitation $\mathrm{NO}_{3}^{-}$in Guangzhou, a severely $\mathrm{N}$-polluted city in China, in an effort to better understand the spatial and seasonal variability of atmospheric $\mathrm{NO}_{\mathrm{x}}$ sources and the formation pathways in this city. We can draw several conclusions from our observations. (1) Positive nitrate $\delta^{15} \mathrm{~N}$ values were observed throughout the year, indicating the importance of $\mathrm{NO}_{\mathrm{x}}$ emissions from coal combustion. Different seasonal patterns of $\delta^{15} \mathrm{~N}^{-\mathrm{NO}_{3}^{-}}$were observed between 2008 and 2009, which might reflect different human activities associated with the global financial crisis and the intensive preparations for the 16th Asian Games. (2) The anthropogenic $\mathrm{NO}_{\mathrm{x}}$ source accounted for $59 \%$ and $55 \%$ of the total precipitation $\mathrm{NO}_{3}^{-}$input in 2008 and 2009, respectively, based on an isotope model. Nevertheless, this may be an underestimation. (3) The observed range of $\delta^{18} \mathrm{O}-\mathrm{NO}_{3}^{-}$values from $+33.4 \%$ o to $+86.5 \%$ o was lower than those reported for high altitude and polar areas, underscoring the importance of $\mathrm{OH}$ radicals in the formation of atmospheric $\mathrm{NO}_{3}^{-}$due to the relative long summer. Sixteen percent of $\delta^{18} \mathrm{O}$ values that were lower than the expected minimum of $+55 \%$ at our study site likely resulted from the reaction of $\mathrm{NO}$ with peroxy radicals; peroxy radicals can compete with $\mathrm{O}_{3}$ to convert $\mathrm{NO}$ to $\mathrm{NO}_{2}$, thereby donate $\mathrm{O}$ atoms with much lower $\delta^{18} \mathrm{O}$ values than that of $\mathrm{O}_{3}$ to atmospheric $\mathrm{NO}_{3}^{-}$.

\section{Supplementary material related to this article is available online at: http://www.atmos-chem-phys.net/11/1313/2011/ acp-11-1313-2011-supplement.pdf.}

Acknowledgements. This work was supported by the National Natural Science Foundation of China (Nos. 30725006, 40703030, 30972365, U0833001, and 40875076), Guangdong Natural Science Foundation of China (No. 8151065005000016), a grant-in-aid for scientific research from Japan Society for Promotion of Science (JSPS) (No. 21310008), Grant for Projects for the Protection, Preservation \& Restoration of Cultural Properties in Japan by The Sumitomo Foundation, Grants-in-Aid for Creative Scientific
Research (Nos. 18380093 and 20780113), the Program to Create an Independent Research Environment for Young Researchers from the Ministry of Education, Culture, Sports, Science and Technology, Japan, the National Program on Key Basic Research Project of China (No. 2010CB428504), and Key laboratory of vegetation restoration and management of degraded ecosystems, South China Botanical Garden, Chinese Academy of Sciences. Y. T. Fang was supported by the JSPS with a Postdoctoral Fellowship for Foreign Researchers and a grant-in-aid for JSPS Fellows (No. 20-08421). We acknowledge Qiaojun Chen for drawing the backward air mass trajectories. We are grateful for constructive comments, remarks and advice from Dr. Samuel Morin and other two anonymous referees.

Edited by: J. Kaiser

\section{References}

Aber, J. D., McDowell, W., Nadelhoffer, K., Magill, A., Berntson, G., Kamakea, M., McNulty, S., Currie, W., Rustad, L., and Fernandez, I.: Nitrogen saturation in temperate forest ecosystems hypothesis revisited, Bioscience, 48, 921-934, 1998.

Alexander, B., Hastings, M. G., Allman, D. J., Dachs, J., Thornton, J. A., and Kunasek, S. A.: Quantifying atmospheric nitrate formation pathways based on a global model of the oxygen isotopic composition $\left(\Delta^{17} \mathrm{O}\right)$ of atmospheric nitrate, Atmos. Chem. Phys., 9, 5043-5056, doi:10.5194/acp-9-5043-2009, 2009.

Ammann, M., Siegwolf, R., Pichlmayer, F., Suter M., Saurer, M., and Brunold, C.: Estimating the uptake of traffic-derived $\mathrm{NO}_{2}$ from N-15 abundance in Norway spruce needles, Oecologia, 118(2), 124-131, 1999.

Baker, A. R., Westin, K., Kelly, S. D., Voss, M., Streu, P., and Cape, J. N.: Dry and wet deposition of nutrients from the tropical Atlantic atmosphere: Links to primary productivity and nitrogen fixation, Deep Sea Res., Part I, 54, 1704-1720, 2007.

Barkan, E. and Luz, B.: High-precision measurements of ${ }^{17} \mathrm{O} /{ }^{16} \mathrm{O}$ and ${ }^{18} \mathrm{O} /{ }^{16} \mathrm{O}$ of $\mathrm{O}_{2}$ and $\mathrm{O}_{2} / \mathrm{Ar}$ ratios in air, Rapid Commun. Mass Spectrom., 17(24), 2809-2814, 2003.

Calvert, J. G., Lazrus, A., Kok, G. L., Heikes, B. G., Walega, J. G., Lind, J., and Cantrell, C. A.: Chemical mechanisms of acid generation in the troposphere, Nature, 317, 27-35, 1985.

Cao, Y. Z., Wang, S. Y., Zhang, G.,Luo, J. Y., and Lu, S. Y.: Chemical characteristic and source assessment of wet precipitation at Mountain Baiyun, Guangzhou, The Administ. Techni. Environ. Monit., 21(6), 20-23, 2009 (in Chinese with English abstract).

Carrillo, J. H., Hastings, M. G., Sigman, D. M., and Huebert, B. J.: Atmospheric deposition of inorganic and organic nitrogen and base cations in Hawaii, Global Biogeochem. Cy., 16(4), 1076, doi:10.1029/2002GB001892, 2002.

Casciotti, K. L., Böhlke, J. K., McIlvin, M. R., Mroczkowski, S. J., and Hannon, J. E.: Oxygen isotopes in nitrite: Analysis, calibration, and equilibration, Anal. Chem., 79(6), 2427-2436, 2007.

Casciotti, K. L., Sigman, D. M., Hastings M. G., Böhlke, J. K., and Hilkert, A.: Measurement of the oxygen isotopic composition of nitrate in seawater and freshwater using the denitrifier method, Anal. Chem., 74(19), 4905-4912, doi:10.1021/ac020113w, 2002.

Chakraborty, S. and Chakraborty, S.: Isotopic fractionation of the $\mathrm{O}_{3}$-nitric oxide reaction, Curr. Sci., 85, 1210-1212, 2003. 
Draxler, R. R. and Rolph, G. D.: HYSPLIT (HYbrid Single-Particle Lagrangian Integrated Trajectory) Model access via NOAA ARL READY Website, available at: http://ready.arl.noaa.gov/ HYSPLIT.php, NOAA Air Resources Laboratory, Silver Spring, MD., 2010.

Ehhalt, D., Prather, M., Dentener, F., Derwent, R., Dlugokencky, E., Holland, E., Isaksen, I., Katima, J., Kirchhoff, V., Matson, P., Midgley, P., and Wang, M.: Atmospheric chemistry and greenhouse gases, in: Climate Change 2001: The Scientific Basis Contribution of Working Group I to the Third Assessment Report of the Intergovernmental Panel on Climate Change, edited by: Houghton, J. T., Ding, Y., Griggs, D. J., Noguer, M., van der Linden, P. J., Dai, K., Maskell, K., and Johnson, C. A., Cambridge University Press, New York, USA, 2001.

Elliott, E. M., Kendall, C., Wankel, S. D., Burns, D. A., Boyer, E. W., Harlin, K., Bain, D. J., and Butler, T. J.: Nitrogen isotopes as indicators of $\mathrm{NO}_{\mathrm{x}}$ source contributions to atmospheric nitrate deposition across the midwestern and northeastern United States, Environ. Sci. Technol., 41(22), 7661-7667, 2007.

Elliott, E. M., Kendall, C., Boyer, E. W., Burns, D. A., Lear, G. G., Golden, H. E., Harlin, K., Bytnerowicz, A., Butler, T. J., and Glatz, R.: Dual nitrate isotopes in dry deposition: Utility for partitioning $\mathrm{NO}_{\mathrm{x}}$ source contributions to landscape nitrogen deposition, J. Geophys. Res., 114, G04020, doi:10.1029/2008JG000889, 2009.

Fang, Y. T., Gundersen, P., Mo, J. M., and Zhu, W. X.: Input and output of dissolved organic and inorganic nitrogen in subtropical forests of South China under high air pollution, Biogeosciences, 5, 339-352, doi:10.5194/bg-5-339-2008, 2008.

Finlayson-Pitts, B. J. and Pitts, J. N.: Chemistry of the upper and lower atmosphere: theory, experiments and applications, Academic Press, San Diego CA, 2000.

Freyer, H. D.: Seasonal trend of $\mathrm{NH}_{4}^{+}$and $\mathrm{NO}_{3}^{-}$nitrogen isotope composition in rain collected at Jülich, Germany, Tellus, 30(1), 83-92, 1978.

Freyer, H. D.: Seasonal variation of ${ }^{15} \mathrm{~N} /{ }^{14} \mathrm{~N}$ ratios in atmospheric nitrate species, Tellus B, 43, 30-44, 1991.

Freyer, H. D., Kley, D., Volz-Thomas, A., and Kobel, K.: On the Interaction of Isotopic Exchange Processes With Photochemical Reactions in Atmospheric Oxides of Nitrogen, J. Geophys. Res., 98(D8), 14, 791-14,796, 1993.

Galloway, J. N., Dentener, F. J., Capone, D. G., Boyer, E. W., Howarth, R. W., Seitzinger, S. P., Asner, G. P., Cleveland, C. C., Green, P. A., Holland, E. A., Karl, D. M., Michaels, A. F., Porter, J. H., Townsend, A. R., and Vorosmarty, C. J.: Nitrogen cycles: Past, present, and future, Biogeochemistry, 70, 153-226, 2004.

Galloway, J. N., Townsend, A. R., Erisman, J. W., Bekunda, M., Cai, Z., Freney, J. R., Martinelli, L. A., Seitzinger, S. P., and Sutton, M. A.: Transformation of the nitrogen cycle: recent trends, questions, and potential solutions, Science, 320, 889-892, 2008.

Goodale, C. L., Thomas, S. A., Fredriksen, G., Elliott, E. M., Flinn, K. M., Butler, T.J., and Walter, M.T.: Unusual seasonal patterns and inferred processes of nitrogen retention in forested headwaters of the Upper Susquehanna River, Biogeochemistry, 93, 197218, 2009.

Gundersen, P., Emmett, A., Kjønaas, O. J., Koopmans, C. J., and Tietema, A.: Impact of nitrogen deposition on nitrogen cycling in forest: a synthesis of NITREX data, For. Ecol. Manag. 101,
37-55, 1998.

Hastings, M. G., Sigman, D. M., and Lipschultz, F.: Isotopic evidence for source changes of nitrate in rain at Bermuda, J. Geophys. Res., 108(D24), 4790, doi:10.1029/2003JD003789, 2003.

Hastings, M. G., Steig, E. J., and Sigman, D. M.: Seasonal variations in $\mathrm{N}$ and $\mathrm{O}$ isotopes of nitrate in snow at Summit, Greenland: Implications for the study of nitrate in snow and ice cores, J. Geophys. Res., 109, D20306, doi:10.1029/2004JD004991, 2004.

Hasting, M. G., Jarvis, J. C., and Steig, E. J.: Anthropogenic impacts on nitrogen isotopes of ice-core nitrate, Science, 324, p. 1288, 2009.

Heaton, T. H. E.: ${ }^{15} \mathrm{~N} /{ }^{14} \mathrm{~N}$ ratios of nitrate and ammonium in rain at Pretoria, South Africa, Atmos. Environ. 21, 843-852, 1987.

Heaton, T. H. E.: ${ }^{15} \mathrm{~N} /{ }^{14} \mathrm{~N}$ ratios of $\mathrm{NO}_{\mathrm{x}}$ from vehicle engines and coal-fired power stations, Tellus B, 42, 304-307, 1990.

Heaton, T. H. E., Wynn, P., and Tye, A. M.: Low ${ }^{15} \mathrm{~N} /{ }^{14} \mathrm{~N}$ ratios for nitrate in snow in the High Arctic $\left(79^{\circ} \mathrm{N}\right)$, Atmos. Environ., 38, 5611-5621, 2004

Hoering, T.: The isotopic composition of the ammonia and the nitrate ion in rain, Geochim. Cosmochim. Acta, 12(1-2), 97-102, 1957.

Hua, W., Chen, Z. M., Jie, C. Y., Kondo, Y., Hofzumahaus, A., Takegawa, N., Chang, C. C., Lu, K. D., Miyazaki, Y., Kita, K., Wang, H. L., Zhang, Y. H., and Hu, M.: Atmospheric hydrogen peroxide and organic hydroperoxides during PRIDE-PRD'06, China: their concentration, formation mechanism and contribution to secondary aerosols, Atmos. Chem. Phys., 8, 6755-6773, doi:10.5194/acp-8-6755-2008, 2008.

Huang, D. Y., Xu, Y. G., Peng, P. A., Zhang, H. H., and Lan, J. B.: Chemical composition and seasonal variation of acid deposition in Guangzhou, South China: Comparison with precipitation in other major Chinese cities, Environ. Pollut., 157, 35-41, 2009.

Liu, J. F., Song, Z. G., and Xu, T.: Study on ionic composition of rainwater at Guangzhou and the primary factors of rainwater acidity, Environ. Sci., 27(10), 1998-2002, 2006 (in Chinese with English abstract).

Jarvis, J. C., Steig, E. J., Hastings, M. G., and Kunasek, S. A.: Influence of local photochemistry on isotopes of nitrate in Greenland snow, Geophys. Res. Lett., 35, L21804, doi:10.1029/2008GL035551, 2008.

Johnston, J. C. and Thiemens M. H.: The isotopic composition of tropospheric ozone in three environments, J. Geophys. Res., 102, 25395-25404, 1997.

Kendall, C., Elliott, E. M., and Wankel, S. D.: Tracing anthropogenic inputs of nitrogen to ecosystem, in: Stable Isotopes in Ecology and Environmental Science, edited by: Lajtha, K. and Michener, R. H., 2nd edition, Wiley-Blackwell Scientific Publication 375-449, 2007.

Kiga, T., Yoshikawa K., Tsunogai, U., Okitsu, S., and Narukawa, $\mathrm{K}$.: Evaluation of $\mathrm{NO}_{\mathrm{x}}$ formation in pulverized coal firing by use of nitrogen isotope ratios, paper presented at International Joint Power Generation Conference, Am. Soc. of Mech. Eng., Miami Beach, Fl, USA, 23-26 July, 2000.

Krankowsky, D., Bartecki, F., Klees, G. G., Mauersberger, K., Schellenbach, K., and Stehr, J.: Measurement of heavy isotope enrichment in tropospheric ozone, Geophys. Res. Lett., 22, 1713-1716, 1995.

Li, D. J. and Wang, X. X.: Nitrogen isotopic signature of soil- 
released nitric oxide (NO) after fertilizer application, Atmos. Environ., 42, 4747-4754, 2008.

Liang, J. Y., Horowitz, L. W., Jacob, D. J., Wang, Y., Fiore, A. M., Logan, J. A., Gardner, G. M., and Munger, J. W.: Seasonal budgets of reactive nitrogen species and ozone over the United States, and export fluxes to the global atmosphere, J. Geophys. Res., 103(D11), 13435-13450, doi:10.1029/97JD03126, 1998.

Liu, J. Q., Keene, W. C., and Wu, G. P.: Study of precipitation background value in Lijiang, China, China Environ. Sci. 13, 246-251, 1993 (in Chinese with English abstract).

Liu, J. F., Song, Z. G., and Xu, T.: Study on ionic composition of rainwater at Guangzhou and the primary factors of rainwater acidity, Environ. Sci., 27(10), 1998-2002, 2006 (in Chinese with English abstract).

Liu, Ying, Shao, Min, Lu, Sihua, Chang, Chih-chung, Wang, JiaLin, and Chen, Gao: Volatile Organic Compound (VOC) measurements in the Pearl River Delta (PRD) region, China, Atmos. Chem. Phys., 8, 1531-1545, doi:10.5194/acp-8-1531-2008, 2008.

Michalski, G., Scott, Z., Kabiling, M., and Thiemens, M. H.: First measurements and modeling of $\Delta^{17} \mathrm{O}$ in atmospheric nitrate, Geophys. Res. Lett., 30(16), 1870, doi:10.1029/2003GL017015, 2003.

Moore, H.: The isotopic composition of ammonia, nitrogen dioxide, and nitrate in the atmosphere, Atmos. Environ., 11, 1239-1243, 1977.

Morin, S., Savarino, J., Frey, M. M., Yan, N., Bekki, S., Bottenheim, J. W., and Martins, J. M. F.: Tracing the origin and fate of $\mathrm{NO}_{\mathrm{x}}$ in the arctic atmosphere using stable isotopes in nitrate, Science, 322(5902), 730-732, 2008.

Morin, S., Savarino, J., Frey, M. M., Domine, F., Jacobi, H. W., Kaleschke, L., and Martins, J. M. F.: Comprehensive isotopic composition of atmospheric nitrate in the Atlantic Ocean boundary layer from $65^{\circ} \mathrm{S}$ to $79^{\circ} \mathrm{N}, \mathrm{J}$. Geophys. Res., 114, D05303, doi:10.1029/2008JD010696, 2009.

Pearson, J., Wells, D. M., Seller, K. J., Bennett, A., Soares, A., Woodall, J., and Ingrouille, M. J.: Traffic exposure increases natural ${ }^{15} \mathrm{~N}$ and heavy metal concentrations in mosses, New Phytol., 147, 317-326, 2000.

Quan, W.Z., Feng, S. Y., and Lu, X. A.: Current status and tendency of acid rain in Guangzhou City, Shanghai Environ. Sci., 11(1), 20-23, 1992 (in Chinese)

Russell, K. M., Galloway, J. N., Macko, S. A., Moody, J. L., and Scudlark, J. R.: Sources of nitrogen in wet deposition to the Chesapeake Bay region, Atmos. Environ., 32, 2453-2465, 1998.

Savarino, J., Kaiser, J., Morin, S., Sigman, D. M., and Thiemens, M. H.: Nitrogen and oxygen isotopic constraints on the origin of atmospheric nitrate in coastal Antarctica, Atmos. Chem. Phys., 7, 1925-1945, doi:10.5194/acp-7-1925-2007, 2007.

Seinfeld, J. and Pandis, S.: Atmospheric Chemistry and Physics, Wiley Interscience, 1998.

Shao, M, Zhang, Y. H., Zeng, L. M., Tang, X. Y., Zhang, J., Zhong, L. J., and Wang, B. G.: Ground-level ozone in the Pearl River Delta and the roles of VOC and $\mathrm{NO}_{\mathrm{x}}$ in its production, J. Environ. Manag., 90 (1), 512-518, 2009.

Sigman, D. M., Casciotti, K. L., Andreani, M., Barford, C., Galanter, M., and Böhlke, J. K.: A bacterial method for the nitrogen isotopic analysis of nitrate in seawater and freshwater, Anal. Chem., 73(17), 4145-4153, 2001.
Snape, C. E., Sun, C., Fallick, A. E., Irons, R., and Haskell, J.: Potential of stable nitrogen isotope ratio measurements to resolve fuel and thermal $\mathrm{NO}_{\mathrm{x}}$ in coal combustion, Prepr. Am. Chem. Soc. Div. Fuel Chem., 48(1), 3-5, 2003.

Tian, H. Z., Hao, J. M., Lu, Y. Q., and Zhu, T. L.: Inventories and distribution characteristics of $\mathrm{NO}_{\mathrm{x}}$ emissions in China, China Environ. Sci., 21(6), 493-497, 2001 (in Chinese with English abstract).

Tsunogai, U., Komatsu, D. D., Daita, S., Kazemi, G. A., Nakagawa, F., Noguchi, I., and Zhang, J.: Tracing the fate of atmospheric nitrate deposited onto a forest ecosystem in Eastern Asia using $\Delta^{17} \mathrm{O}$, Atmos. Chem. Phys., 10, 1809-1820, doi:10.5194/acp10-1809-2010, 2010

Vitousek, P. M., Aber, J. D., Howarth, R. W., Likens, G. E., Matson, P. A., Schindler, D. W., Schlesinger, W. H., and Tilman, D. G.: Human alteration of the global nitrogen cycle: Sources and consequences, Ecol. Appl., 7, 737-750, 1997.

Wang, T., Poon, C. N., Kwok, Y. H., and Li, Y. S.: Characterizing the temporal variability and emission patterns of polluting plumes in the Pearl River Delta of China, Atmos. Environ. 37, 3539-3550, 2003.

Wang, Y., McElroy, M. B., Martin, R. V., Streets, D. G., Zhang, Q., and Fu, T. M.: Seasonal variability of $\mathrm{NO}_{\mathrm{x}}$ emissions over east China constrained by satellite observations: Implications for combustion and microbial sources, J. Geophys. Res., 112, D06301, doi:10.1029/2006JD007538, 2007.

Wang, H. K., Fu, L. X., Zhou, Y., Du, X., and Ge, W. H.: Trends in vehicular emissions in China's mega cities from 1995 to 2005 , Environ. Pollut., 158, 394-400, 2010.

Wankel, S. D., Chen, Y., Kendall, C., Post, A. F., and Paytan, A.: Sources of aerosol nitrate to the Gulf of Aqaba: Evidence from $\delta^{15} \mathrm{~N}$ and $\delta^{18} \mathrm{O}$ of nitrate and trace metal chemistry, Mar. Chem., 120(1-4), 90-99, 2010.

Widory, D.: Nitrogen isotopes: Tracers of origin and processes affecting $\mathrm{PM}_{10}$ in the atmosphere of Paris, Atmos. Environ., 41, 2382-2390, 2007.

Ye, S. D., Liu, J. J., and Wu, R. H.: Analysis on the chemical characteristics and variation tendency of precipitation in Guangzhou City, Acta Scientiarum Naturalium Universitatis Sunyatseni, 47(sup.), 43-47, 2008 (in Chinese with English abstract)

Yeatman, S. G., Spokes, L. J., Dennis, P.F., Jickells, T. D.: Comparison of aerosol nitrogen isotopic composition at two polluted coastal sites, Atmos. Environ., 35, 1307-1320, 2001.

Zhang, Y. H., Su, H., Zhong, L. J., Cheng, Y. F., Xiang, Y. R., Wang, J. L., Gao, D. F., Shao, M., Fan, S. J., and Liu, S. C.: Regional ozone pollution and observation-based approach for analyzing ozone-precursor relationship during the PRIDE-PRD2004 campaign, Atmos. Environ., 42(25), 6203-6218, 2008a.

Zhang, Y., Liu, X. J., Fangmeier, A., Goulding, K. T. W., and Zhang, F. S.: Nitrogen inputs and isotopes in precipitation in the North China Plain, Atmos. Environ. 42 1436-1448, 2008b.

Zhao, Y., Duan, L., Xing, J., Larssen T., Nielsen C. P., and Hao J. M.: Soil acidification in China: Is controlling $\mathrm{SO}_{2}$ emissions enough?, Environ. Sci. Tech., 43(21), 8021-8026, 2009.

Zheng, J. Y., Zhang, L. J., Che, W. W., Zheng, Z. Y., and Yin, S. S.: A highly resolved temporal and spatial air pollutant emission inventory for the Pearl River Delta region, China and its uncertainty assessment, Atmos. Environ., 43, 5112-5122, 2009. 